\title{
Combined heat, cooling, and power systems based on half effect absorption chillers and polymer electrolyte membrane fuel cells
}

\author{
Gabriele Loreti ${ }^{\mathrm{a}}$, Andrea L. Facci ${ }^{\mathrm{a}, *}$, Ilaria Baffo ${ }^{\mathrm{a}}$, Stefano Ubertini ${ }^{\mathrm{a}}$ \\ ${ }^{a}$ Department of Economics, Engineering, Society and Business Organization, University of Tuscia, 01100 Viterbo, Italy.
}

\begin{abstract}
Fuel cell based trigeneration plants, that utilize absorption chillers to convert waste heat into cooling energy, are a promising technology to satisfy heat, power, and cooling demand in warm climates. Polymer electrolyte membrane fuel cells, that operate at low temperature $\left(<100^{\circ} \mathrm{C}\right)$, are the most technologically mature among the several types of fuel cells. Thermally activated cooling technologies are widely utilized in trigeneration plants to improve their efficiency. However, absorption chillers require relatively high grade thermal energy and their coupling with low temperature fuel cells is relatively untapped.

Herein, we perform a techno-economic analysis of a trigeneration plant based on low temperature polymer electrolyte membrane fuel cells and half-effect absorption chillers. A thermo-chemical model is developed to estimate the performance of a cogeneration plant based on low temperature fuel cells and of the half-effect absorption chiller. The behavior of such combined heat, cooling, and power plant is also analyzed within real energy management scenarios, considering different energy demands, climatic conditions, energy costs, and plant layouts. The control strategy of the power plant is optimized through a graph-based methodology previously developed and validated by the authors. Total energy cost and $\mathrm{CO}_{2}$ emissions are then compared to those of a reference scenario where electricity is acquired from the distribution grid, thermal energy is produced through a natural gas boiler, and a mechanical chiller is used for cooling.

The results show that the utilization of half-effect absorption chillers boosts the environmental and economic benefits for all the considered scenarios. We also demonstrate that the utilization of the absorption chiller reduces the imbalance between the results obtained for the different scenarios (i.e. climates), although economic and environmental benefits associated to distributed generation are strongly influenced by the energy context.
\end{abstract}

Keywords: PEMFC CHCP, Half-effect absorption chiller, Power plant modeling, Optimization, GHG

\section{Introduction}

Worldwide, $38.0 \%$ of the final energy is consumed in residential and commercial buildings [1]. Specifically, $45.0 \%$ of such an energy is utilized in OECD countries. Moreover, in 2010, the building sector caused $30.0 \%$ of $\mathrm{CO}_{2}$ emissions related to energy usage [2]. Several factors, such as the increase of households, the population rise, and the fragmentation of households, will increase heating, cooling, and electrical energy consumption in the next years, despite efficiency improvements in the final use [1-3]. Combined Heating and Power (CHP) systems in combination with district heating and cooling are a possible alternative to the business as usual that could bring $\mathrm{CO}_{2}$ emissions savings for about 950 Mton/year [4] by 2030.

Fuel Cells (FCs) are a promising and diffusing technology in the stationary field, especially often used as prime movers for CHP plants in residential and commercial applications [5-

\footnotetext{
* Corresponding author. Tel.: +390761 357676.

Email addresses: gabriele. loreti@unitus. it (Gabriele Loreti), andrea. facci@unitus.it (Andrea L. Facci),

ilaria.baffo@unitus.it (Ilaria Baffo),

stefano.ubertini@unitus.it (Stefano Ubertini)
}

10]. The most relevant advantages of FCs are: (i) the high efficiency [11] that is not a function of the size and that increases at part load [12-14]; (ii) the low level of pollutant emissions [15]; (iii) the absence of moving parts, that results in less energy dissipation, no mechanical wear, no noise and no vibrations $[14,16]$. For these reasons, more than the $60.0 \%$ of the micro-cogeneration [17] systems sold in 2012 are FCs based $[7,18,19]$. Moreover, the possibility to use hydrogen fueled systems as long term electrical energy storage [20,21], could represent the perfect match with the growing penetration of renewable energy systems [22].

Nowadays, among the different kinds of fuel cells available for commercialization, Polymer Electrolyte Membrane Fuel Cells (PEMFCs) rule the market. In fact, in 2017, the $75 \%$ of newinstalled FC units were based on polymer electrolyte membrane fuel cells [23]. Moreover, PEMFCs market share is growing and in 2016 it accounted for the $65 \%$ of new FC units. Such a success is mainly due to technological readiness and to the favorable performance at part load $[13,14,24]$. Despite $90 \%$ of the polymer electrolyte membrane fuel cells newly-installed megawatts are used for transportation [23], the importance of such devices in the stationary field is still relevant. A great part of stationary FC-based units are installed within the Japanese 
ENE-FARM project, that mainly focuses on PEMFCs [23, 25].

The concept of CHP systems was originally developed in 1880's [5], however it is recently catching the attention for several economical, environmental, and energetic reasons: (i) higher total efficiency if compared to separated production $[12,26]$, (ii) less emissions of greenhouse gases and pollutants [26, 27], (iii) investment reduction on large centralized power plants and distribution lines [26, 27], (iv) lower distribution losses [27], (v) subsidiary service to the main electrical energy distribution grid [27], (vi) natural inclination to new and alternative technologies, especially towards renewable energy sources[20, 26, 28-30]. Moreover, it is possible to incorporate a thermally activated cooling machine in a CHP plant in order to make thermal integration more effective in warm months and climates. Accordingly, a Combined Heat, Cooling, and Power (CHCP) plant is established [31].

Several thermally activated cooling technologies exist: absorption chillers [32, 33], adsorption chillers [32, 34] and desiccant cooling systems [32, 35]. Absorption chillers are the most established technology with variety of plant schemes as a function of the specific application $[32,33]$. Double-effect absorption chillers are the most efficient and can be used if high quality heat is available (i.e. for temperatures between $120^{\circ} \mathrm{C}$ and $220^{\circ} \mathrm{C}$ ). Single effect absorption chillers can be used with an heat source temperature in the range $\left[80^{\circ} \mathrm{C} ; 120^{\circ} \mathrm{C}\right]$, and have a Coefficient Of Performance (COP) between 0.5 and 0.7 . Finally, the half-effect scheme can work with heat at a temperature below $80^{\circ} \mathrm{C}$, that could not be used in other kinds of absorption chillers. Such a feature is fundamental when a PEM fuel cell is the prime mover of the CHP plant.

The investment cost is the main obstacle to fuel cells diffusion. A survey on the market of FC CHP systems is reported in Table 1. These data show that commercial CHP systems costs [36-45] are far higher than the Fuel Cells and Hydrogen Joint Undertaking (FCH-JU) goals, that are between $3500 € / \mathrm{kW}$ and $6500 € / \mathrm{kW}$ for energy systems with a nominal power in the range [5 $\mathrm{kW}-400 \mathrm{~kW}$ ] [46]. Moreover, a detailed techno-economic analysis [5] evidences that the cost of FCs for CHP applications should be lower than $3000 € / \mathrm{kW}$ to be competitive with internal combustion engines.

The mobility market volume is much bigger than the stationary sector one. In fact, about $68 \%$ of the power of the FC energy systems developed in 2017 is attributable to transport applications [23]. Moreover, it is widely acknowledged that the cost of energy systems decreases as the production volume increases [42, 47-49]. For these reasons, the usage of automotive derivative PEMFCs for stationary systems could be useful to reduce the investment costs of this technology $[50,51]$. As a consequence, it is possible to build a constructive collaboration between two non-competitive industrial sectors, that could be crucial for FC CHP power plants development. This is the goal of the AutoRE project $[50,51]$, that aims at the establishment of the basis for the commercialization of an automotive derivative PEMFC based CHP system with a capital cost of $2000 € / \mathrm{kW}$ and in the power range between $50 \mathrm{~kW}$ and $100 \mathrm{~kW}$.

The automotive derivative PEMFC CHP system has already been studied in a thorough techno-economic analysis and, when

\begin{tabular}{lllll}
\hline \hline Model & CHP & $\begin{array}{l}\text { Cost } \\
{[\mathrm{k} €[}\end{array}$ & $\begin{array}{l}\text { Power } \\
{[\mathrm{kW}]}\end{array}$ & $\begin{array}{l}\text { Electrical } \\
\text { Efficiency }\end{array}$ \\
\hline Ballard ClearGEN [37] & Yes & NA & 500 & $40 \%$ \\
Ballard ElectraGen [38] & No & $17-50$ & $1.7-5$ & $40 \%$ \\
Baxi Gamma Premio [39] & Yes & NA & 1 & $34 \%$ \\
$\begin{array}{l}\text { Doosan FC Purocell } 5 \\
\text { [40] }\end{array}$ & Yes & NA & 440 & $43 \%$ \\
Elcore 2400 [39, 41] & Yes & 9 & 0.3 & $33 \%$ \\
Panasonic [39, 42] & Yes & $20-30$ & 0.75 & $37 \%-40 \%$ \\
Inhouse 5000+ [43] & Yes & NA & $1.5-5$ & $34 \%$ \\
Toshiba [39] & Yes & $20-30$ & 0.7 & $35 \%$ \\
Tropical NG-5 [44] & NO & NA & 5 & NA \\
Viessmann [39, 45] & Yes & 36 & 0.75 & $39 \%$ \\
Eneos [42] & Yes & $24.5-$ & 0.7 & NA \\
& & 28.5 & & \\
\hline \hline
\end{tabular}

Table 1: Examples of PEM Fuel cell energy systems available in the market or in a pre-commercial stage in the power range $0-500 \mathrm{~kW}$.

used together with a mechanical chiller, provide economical benefits, with respect to business as usual scenario, for a wide range of climatic conditions and for different users (e.g. commercial, residential, or services) [36]. This is especially true if the CHP plant is managed through an optimized control strategy that maximize economical savings [36]. However, in some cases, depending on the climate and on the primary energy factor and $\mathrm{CO}_{2}$ emission factor of the electricity grid, the environmental impact of such a power plant can be higher than in the reference scenario [36].

In this study, to avoid such a drawback, we maximize the thermal energy recovery throughout the whole year, by utilizing an absorption chiller. Accordingly, it could be possible to reduce the $\mathrm{CO}_{2}$ emissions, while increasing the fuel cell utilization factor, also positively impacting the economic performance.

Few works study the integration of an absorption chiller in a low temperature PEMFC CHP systems [52]. However, a thorough techno-economic analysis of such an innovative energy system is still a relatively untapped topic.

We hypothesize that the plant satisfies the energy demand of an apartment district in Europe. We selected this case among those presented in [36] because its economic performance is brilliant while the plant efficiency is less outstanding due to the low heat demand during warm seasons.

The paper is organized as follows. The considered CHCP system is presented in section 2 . In section 3 we discuss the numerical modeling of the power plant. In section 4 the principles of the techno-economic analysis are presented. The results are presented and discussed in section 5. Finally, in section 6, we draw the conclusions of the work.

\section{Problem statement}

The aim of this paper is to assess the environmental and economic impact of the integration of a half-effect absorption chiller in a PEMFC based CHP plant. 


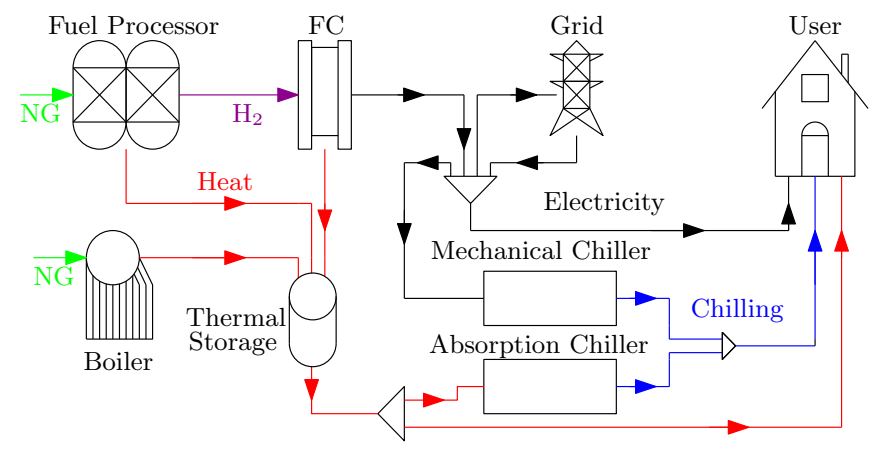

Figure 1: Schematic representation of the considered CHCP plant.

We study the low temperature PEMFC CHP system, represented in Figure 1, that is connected directly to the Natural Gas (NG) line through a fuel processor [53-55]. A CHP system based on the same prime mover was already studied in $[36,53]$ for different energy demands. Therein, it was evidenced that a low heat demand during warm seasons reduces the FC utilization and the plant efficiency. Herein, we evaluate the integration within the plant of an half-effect absorption chiller [52], in order to exploit the low grade heat also in warm months.

First, we retrieve the performance of the components of the $\mathrm{CHCP}$ plant, as a function of the set point through thermochemical lumped parameter models (see section 3 ). Then, we study the behavior of the resulting CHCP system in different energy management scenarios [36]. To this aim, we compare the energy consumption and costs to a reference scenario where electricity is acquired from the distribution grid, heat is produced within a NG boiler, and a mechanical chiller is used for cooling. This scenario represents the state of the art of energy supply for domestic users. We consider the energy demand of a typical apartment district in 5 different climatic conditions (Cold, Heating Based, Moderate, Chilling Based, and Hot) in the European energy context and we evaluate an optimized control strategy, determined through a graph-based approach [56-59].

\subsection{Fuel Cell Based CHCP Plant}

The prime mover of the plant is an automotive derivative PEMFC system with nominal electrical power of $50 \mathrm{~kW}_{\mathrm{el}}$, whose schematics are reported in Figure 2. The fuel cell has been designed and produced by NuCellSys for the application in a small series of the Mercedes-Benz B-Class F-Cell produced from 2009. The FC based powertrain reliability has been demonstrated within a test of more than $300.000 \mathrm{~km}$ of harsh driving conditions on a single car. The automotive derivative PEMFC system is made of the fuel cell and a control system that regulates hydrogen and oxygen flows according to the operating conditions [50, 51].

The FC generates electricity and heat via the catalytic oxidation of pure hydrogen. Its working temperature is $80^{\circ} \mathrm{C}$ and low grade heat can be recovered from the cooling circuit of the bipolar plates (exchanger HTCOOL in Figure 2), and from the cathodic exhaust (exchanger COG in Figure 2). The cogeneration heat is harvested through a water flow (Cogeneration in Figure 2) that enters the heat recovery system at $60^{\circ} \mathrm{C}$. Two kW of thermal power at $60^{\circ} \mathrm{C}$ are wasted towards the environment (exchanger LTCOOL in Figure 2). Such an heat flow is not considered for cogeneration because its low temperature does not allow heat recovery.

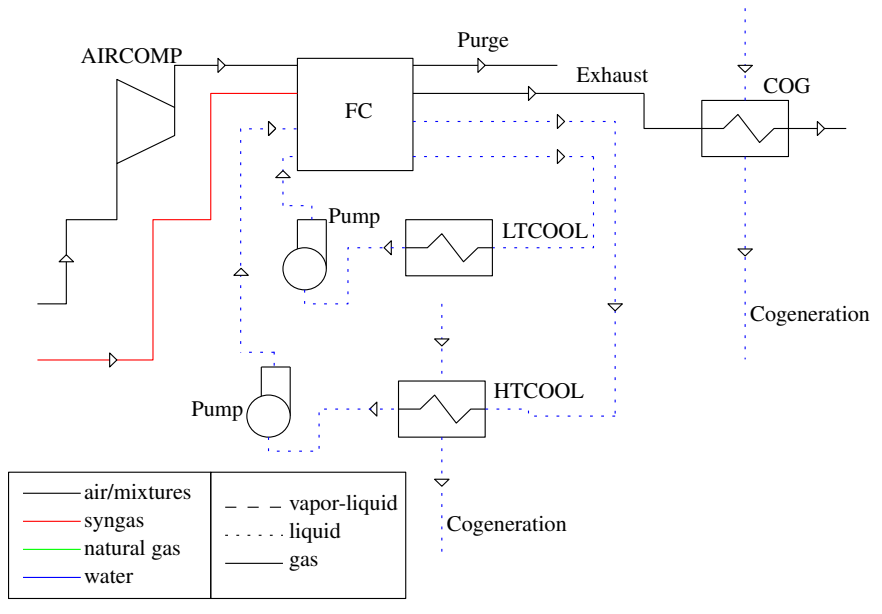

Figure 2: PEMFC based CHP plant scheme.

The high purity $\mathrm{H}_{2}$, necessary to feed the prime mover, is generated from natural gas [60], available from the distribution grid, through the fuel processor schematically depicted in Figure 3 .

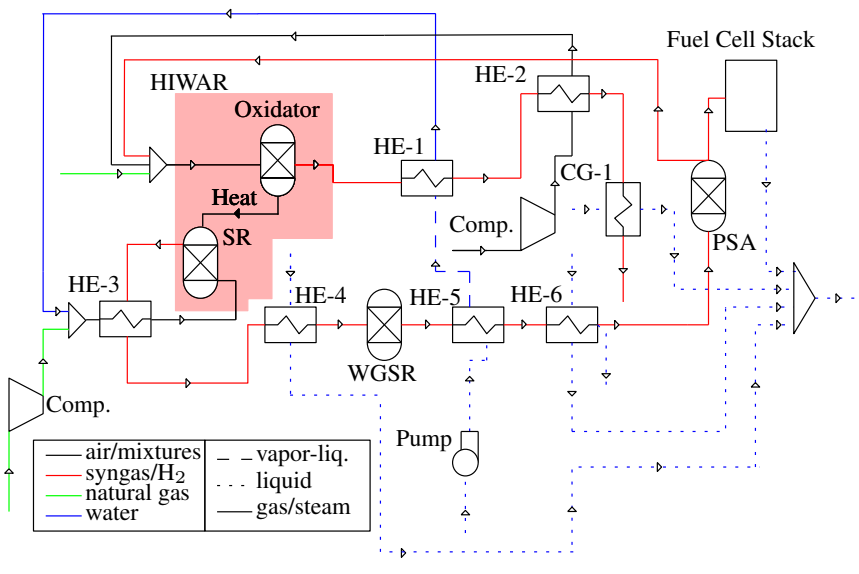

Figure 3: PEMFC based CHP plant scheme, including fuel processing unit.

Such a fuel processor is based on three main elements: (i) Heat Integrated Wall Reactor (HIWAR) [61, 62], (ii) water gas shift reactor, (iii) pressure swing adsorption purification unit. The HIWAR reactor is a compound reactor made of a NG burner and a NG steam reformer. It is a tubular reactor where the inner surface of each tube is coated with the combustion catalysts and the outer surface with the reforming catalysts. In the inside of the HIWAR tubes the catalytic combustion of natural gas, together with air and tail gases from the PSA unit, is performed at ambient pressure and a temperature of $845^{\circ} \mathrm{C}$. The relatively low combustion temperature limits the pollutants (i.e. $\mathrm{NO}_{\mathrm{x}}$ ) generation. The combustion is necessary to produce the heat for the steam reforming that takes place at the outside of the 
HIWAR tubes at $770{ }^{\circ} \mathrm{C}[14,24,63]$, and 12 bar [14, 64, 65]. The heat is produced very close to where it is needed, and the heat transfer is very efficient through the metallic tube wall. The reforming reaction produces a syngas mainly composed by $\mathrm{H}_{2}, \mathrm{CO}_{2}$, and $\mathrm{CO}$. The water gas shift reaction is performed at $320^{\circ} \mathrm{C}$ to shift the catalysts-poisoning $\mathrm{CO}$ into $\mathrm{CO}_{2}$, while producing further hydrogen. Finally, the PSA purification unit is necessary to separate the impurities from the syngas. In fact, the low temperature automotive derivative PEMFC requires a feeding flow made by $99.999 \%$ of hydrogen, according to SAE J2719 [66].

All the other elements of the fuel processing plant are heat exchangers, necessary for thermal integration, or auxiliaries used to guarantee the right pressure levels. Relatively high temperature heat is available from HE-4, HE-6, and CG-1 of the fuel processing plant.

The cooling system studied is a $\mathrm{H}_{2} \mathrm{O} / \mathrm{LiBr}$ half-effect absorption chiller [32, 33, 67, 68], whose Dühring schematic is reported in Figure 4.

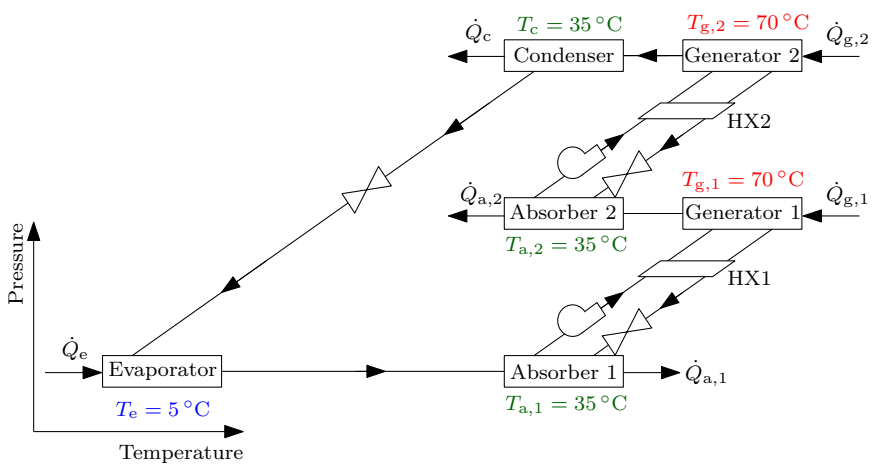

Figure 4: Half-effect absorption chiller Dühring schematic.

The half-effect absorption chiller is a three pressure level machine [67]. The low and high pressure levels are identical to traditional single effect absorption chillers. The intermediate pressure level generator produces refrigerant water vapor that is absorbed in absorber 2. In generator 2 the $\mathrm{H}_{2} \mathrm{O} / \mathrm{LiBr}$ solution is heated again at high pressure to generate the refrigerant that then flows in condenser, evaporator, and absorber 1, as usual.

The three pressure levels structure is similar to that of doubleeffect absorption chillers. However, for half-effect machines the two step absorption-compression-generation process is conceived to exploit low grade heat, rather than high grade heat. In fact, thanks to the intermediate pressure level the generators can operate at a temperature in the range $\left[60^{\circ} \mathrm{C}, 80^{\circ} \mathrm{C}\right]$ $[32,33,67,68]$. Thermal energy in such a temperature range would not be exploitable through a traditional single effect absorption chiller.

The COP of half-effect absorption chillers is lower than the COP of single effect absorption chillers because the double absorption-compression-generation process furnishes heat twice in the generators, while there is a single useful effect in the evaporator.

The generation of refrigerant vapor at low pressure is possible thanks to the properties of the $\mathrm{H}_{2} \mathrm{O} / \mathrm{LiBr}$ solution. In fact, given a certain generator temperature and solution mass flow rate, the higher is the water concentration in the binary solution, the higher will be the mass flow rate of pure refrigerant generated. In other terms, it is possible to obtain the same refrigerant mass flow rate, using a lower generator temperature, with a solution richer in water. However, the maximum amount of water that can be absorbed in $\mathrm{LiBr}$ is limited by its solubility [69]. In addition, the refrigerant generation process is favored by decreasing the working pressure.

The water concentration within the solution in absorber 1 (see Figure 4) is limited by the low pressure that, in turn, is determined by the saturation pressure of the refrigerant at the temperature of the evaporator. Anyway, in generator 1 a reasonable refrigerant mass flow rate can be separated despite the low temperature $\left(60^{\circ} \mathrm{C}<T_{\mathrm{g}, 1}<80^{\circ} \mathrm{C}\right)$, thanks to the relatively low pressure. In absorber 2 the water concentration in the solution is incremented due to solubility increase with pressure. For this reason in generator 2 it is possible to obtain a good refrigerant generation, also at a relatively low generator temperature $\left(60{ }^{\circ} \mathrm{C}<T_{\mathrm{g}, 2}<80^{\circ} \mathrm{C}\right)$.

\section{Numerical Modeling of the CHCP Plant}

\subsection{CHP plant modeling}

We perform the steady-state characterization of the PEMFC based CHP system with a thermo-chemical model, developed following a lumped parameter approach within the AspenPlus ${ }^{\circledR}[70]$ modeling environment. The thermal integration of the components have been refined $[54,55]$ with respect to the prototype studied in [53]. Specifically the heat exchanger surface area is increased such that the pinch point temperature difference in all elements is set to $10^{\circ} \mathrm{C}$, to increase the fuel processor efficiency. As a consequence the electrical efficiency at nominal power is increased up to $36.2 \%$.

We underline that Aspen Plus ${ }^{\circledR}$ is a thermodynamic modeling software based on a lumped parameter approach. Thus, heat exchangers are characterized using a logarithmic mean temperature difference modeling that takes into account only input and output conditions. However, the heat capacity can vary during the heat exchange process, as a consequence of phase changes of one or more species. In these situations, the constant heat capacity assumption underlying the logarithmic mean temperature difference approach is not longer valid and the thermal resistance calculated by the software can be incorrect. Such a wrong evaluation of the thermal resistance cause a wrong estimation of the heat exchanged in off-design conditions. To overcome this problem, we divide each heat exchanger in several fictitious elements, as evidenced in Figure 5. The heat exchange process is thus discretized in small sub-processes, in which the heat capacity can be considered constant. The number of discretization steps is determined through a convergence analysis based on the output enthalpy of hot and cold streams. As the most critical case converges in 10 discretization steps, all the heat exchangers are split in 10 elements. 


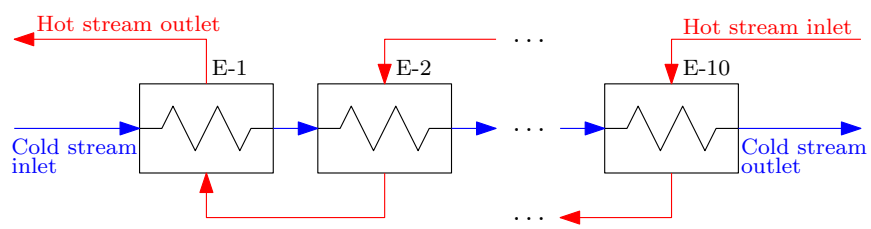

Figure 5: Discretization process for heat exchangers.

Through the model presented in section 3.1 we are able to evaluate the overall electrical efficiency, defined as:

$$
\eta_{\mathrm{el}, \mathrm{CHP}}=\frac{\dot{P}_{\mathrm{el}, \mathrm{CHP}}}{\dot{m}_{\mathrm{NG}} \mathrm{LHV}_{\mathrm{NG}}},
$$

where $\dot{P}_{\mathrm{el}, \mathrm{CHP}}$ is the CHP net electrical power, $\dot{m}_{\mathrm{NG}}$ is the total natural gas mass flow entering in the energy system, and $\mathrm{LHV}_{\mathrm{NG}}=46.5 \mathrm{MJ} / \mathrm{kg}$ is the lower heating value of the natural gas. In addition, we evaluate the thermal efficiency through eq. (2).

$$
\eta_{\mathrm{th}, \mathrm{CHP}}=\frac{\dot{P}_{\mathrm{th}, \mathrm{CHP}}}{\dot{m}_{\mathrm{NG}} \mathrm{LHV}_{\mathrm{NG}}},
$$

where $\dot{P}_{\text {th,CHP }}$ is the thermal power available via co-generation from the CHP plant.

The efficiency values are functions of the plant set point, that is defined as the ratio between the effective and the nominal electrical power (see eq. (3)).

$$
\Phi_{\mathrm{CHP}}=\dot{P}_{\mathrm{el}, \mathrm{CHP}} / \dot{P}_{\mathrm{el}, \mathrm{CHP}}^{\mathrm{nom}},
$$

where $\dot{P}_{\mathrm{el}, \mathrm{CHP}}^{\text {nom }}=50.0 \mathrm{~kW}$ is the nominal electrical power, and $\dot{P}_{\mathrm{el}, \mathrm{CHP}}$ is the power outputs obtained by regulating the power plant.

\subsection{Absorption chiller modeling}

We model also the half-effect absorption chiller within the AspenPlus ${ }^{\circledR}[70]$ environment. Despite several modeling methodologies are available for this kind of study, such as ABSIM [71, 72] and Engineering Equation Solver (EES)[68, 73-76], AspenPlus ${ }^{\circledR}$ was chosen due to its widely tested reliability and to its profitable usage in several recent works $[52,77]$ regarding absorption chillers. Moreover, such an approach has been validated with results provided by others simulation environments, such as EES [77].

Due to the low pressure of the water/lithium bromide solution, we compute the thermodynamic properties of working fluids through the activity coefficient method. Specifically, we use the Redlich-Kwong equation of state [78] for the vaporphase properties together with the Non-Random Two Liquid (NRTL) model [79] for the liquid solution. Such an approach is implemented in AspenPlus ${ }^{\circledR}$ within the ELECNRTL property method. In addition, for pure water streams, the steamNBS tables implemented in AspenPlus ${ }^{\circledR}$ are used [80].

We assume that the water exiting the condenser is saturated liquid. Such a parameter can be easily controlled by varying the heat wasted towards the environment, for example through a variable speed fan. Moreover, we assume that the refrigerant just outside the evaporator is saturated vapor. The two absorbers and the condenser are considered surrounded by the same ambient temperature, that in design conditions, is considered $T_{\text {env }}=30^{\circ} \mathrm{C}$. To guarantee an effective heat exchange, such elements are operated at $T_{\mathrm{a}, 1}=T_{\mathrm{a}, 2}=T_{\mathrm{c}}=35^{\circ} \mathrm{C}$. As a consequence, their pressure is $p^{\text {high }}=5.80 \mathrm{kPa}$. For off-design environmental conditions $p^{\text {high }}$ is varied according to the temperature variation.

We assume that the cooling fluid is released to the user at $T_{\text {us }}=10^{\circ} \mathrm{C}$. Such an assumption implies that the evaporator is operated at a temperature $T_{\mathrm{e}}=5{ }^{\circ} \mathrm{C}$. To obtain evaporation at such a temperature, the lower level pressure is fixed to $p^{\text {low }}=$ $0.873 \mathrm{kPa}$.

We consider the intermediate pressure level at $p^{\mathrm{int}}=2.00 \mathrm{kPa}$. Such a value is commonly recognized to be the best trade-off to increase the overall performance $[52,76,77]$.

Given the temperature, $T_{\mathrm{a}, 1}=T_{\mathrm{a}, 2}=35^{\circ} \mathrm{C}$, and pressure at both low and intermediate aborbers, it is possible to determine the minimum lithium bromide concentration necessary to absorb all the refrigerant [69]. In absorber 1 we obtain $x_{\mathrm{LiBr}}^{\text {low }}=56.0 \%$ mass fraction, while at the intermediate pressure level we get $x_{\mathrm{LiBr}}^{\mathrm{int}}=46.0 \%$.

The expansions in the valves are isoenthalpic processes.

We model the generators utilizing two elements: a heat exchanger and a flash separator (see Figure 6).

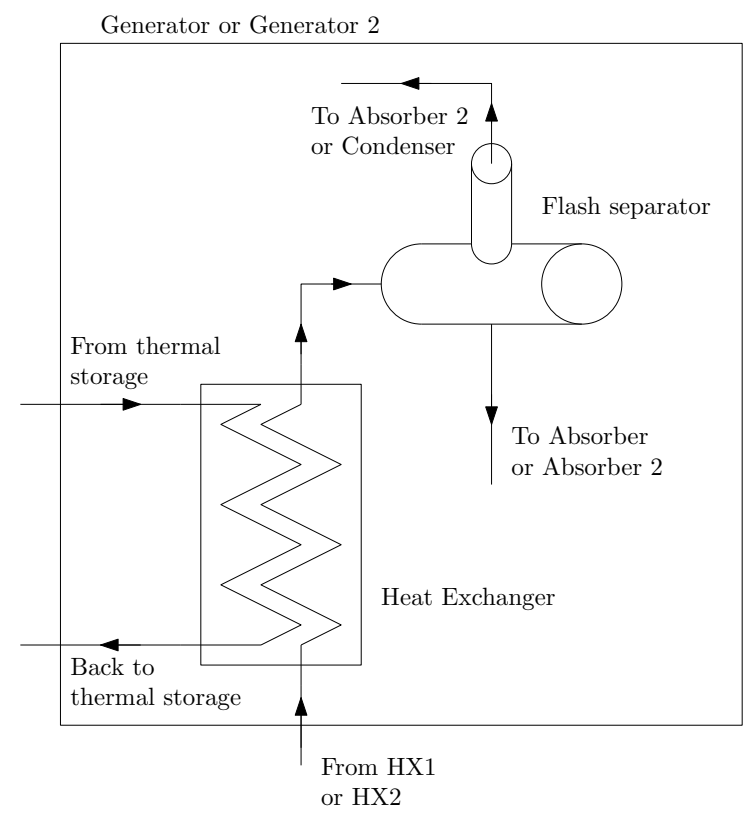

Figure 6: Modeling scheme of the generators.

The condenser, the evaporator, and the two absorbers are modeled as single flux heat exchanger where just the output desired conditions are specified. In fact, in the real chiller the $\mathrm{H}_{2} \mathrm{O} / \mathrm{LiBr}$ solution exchanges heat with external air in these elements. Then, the air flow can be regulated with an adjustable speed fan. As a consequence, the output desired conditions can be accomplished for every working condition. Pumps and valves are also modeled with built-in AspenPlus ${ }^{\circledR}$ functions. 
The solution mass flow rates in the lower pressure level circuit is manipulated in order to guarantee a constant generator temperature $T_{\mathrm{g}, 1}=70^{\circ} \mathrm{C}$, also at part load. The mass flow rate of the refrigerant generated in generator 2 and in generator 1 is the same to guarantee the mass balance of the low pressure circuit. Such a condition is obtained by varying the solution mass flow rate in the high pressure cycle.

The absorption chiller is sized to use, at full load, all the heat produced from the fuel cell in nominal conditions. Accordingly, a nominal cooling power of $29.5 \mathrm{~kW}$ is obtained.

Counter current heat exchangers are used for HX1, HX2, and for generator 1 and generator 2 . Such elements are studied through the logarithmic mean temperature difference approach. An accurate modeling of the off-design performance is considered, since the thermal resistance varies as a function of the pure hydrogen mass flow produced that is the main parameter for sensitivity analyses. The product of heat exchange coefficient $U^{*}$ and area $A$ is calculated under design conditions as [81]:

$$
U^{*} A=\dot{Q} / \Delta \mathrm{T}_{\mathrm{ml}},
$$

where $\dot{Q}$ is the thermal power and $\Delta \mathrm{T}_{\mathrm{ml}}$ the logarithmic mean temperature difference. Both $\dot{Q}$ and $\Delta \mathrm{T}_{\mathrm{ml}}$ are known because we know the inlet conditions and mass flows, and we set output conditions, assuming a pinch point temperature difference of $5^{\circ} \mathrm{C}$.

When mass flow rates change, the thermal resistance is calculated as:

$$
U A=U^{*} A\left(\dot{m} / \dot{m}^{*}\right)^{0.8},
$$

where $\dot{m}$ and $\dot{m}^{*}$ are the mass flow rates in off-design and design conditions, respectively. When $\dot{m} / \dot{m}^{*}$ is different for the hot and the cold side of the heat exchanger, the mass flow with the lower heat transfer coefficient is considered in eq. (5).

To calculate the performance of the half-effect absorption chiller in off-design we vary the cogenerated mass flow rate that guarantees heat to the generators. In this case, the main performance indicator is the coefficient of performance:

$$
\eta_{\mathrm{co}, \mathrm{AC}}=\frac{\dot{P}_{\mathrm{co}, \mathrm{AC}}}{\dot{Q}_{\mathrm{g}, 1}+\dot{Q}_{\mathrm{g}, 2}},
$$

where $\dot{P}_{\mathrm{co}, \mathrm{AC}}=\dot{Q}_{\mathrm{e}}$ is the cooling power generated in the evaporator. $\dot{Q}_{\mathrm{g}, 1}$ and $\dot{Q}_{\mathrm{g}, 2}$ are the thermal power required respectively in low and high pressure generators: generator 1 and generator 2 in Figure 4 . We represent the results as functions of the following cooling set point:

$$
\Phi_{\mathrm{AC}}=\dot{P}_{\mathrm{co}, \mathrm{AC}} / \dot{P}_{\mathrm{co}, \mathrm{AC}}^{\mathrm{nom}},
$$

where $\dot{P}_{\mathrm{co}, \mathrm{AC}}^{\text {nom }}=29.5 \mathrm{~kW}$ is the nominal cooling power, and $\dot{P}_{\mathrm{co}, \mathrm{AC}}$ the power obtained by regulating the absorption chiller.

\section{Techno-economic analysis}

\subsection{Power Plant configurations}

To evaluate the impact of thermally driven refrigeration on the CHP plant performance, we compare the three main plant configurations, summarized in Table 2.

\begin{tabular}{l|ccc}
\hline \hline & Reference & Case A & Case B \\
\hline CHP Plant & $x$ & $\checkmark$ & $\checkmark$ \\
Absorption Chiller & $x$ & $x$ & $\checkmark$ \\
Mechanical Chiller & $\checkmark$ & $\checkmark$ & $\checkmark$ \\
\hline \hline
\end{tabular}

Table 2: Power plant configurations analyzed.

Specifically, we study the reference scenario where electricity is brought from the distribution grid, heat is produced through a NG boiler and a mechanical chiller is used to satisfy the cooling load. In Case A, we consider the CHP system in study together with the mechanical chiller. Finally, Case B power plant utilizes the half-effect absorption chiller added to Case A energy system.

The mechanical chiller and the boiler are always present and sized to satisfy the peak demand of each case. The fuel cell CHP based system has a nominal power of $50 \mathrm{~kW}$.

Also in Case B the mechanical chiller is able to fulfill the peak cooling demand to maximize the plant flexibility. The thermal storage is always considered and has the same power of the fuel boiler and it has a capacity equivalent to three hours of peak demand.

Figure 7 reports the performance of the mechanical chiller and of the fuel boiler as functions of the set point. Data are retrieved from literature [82]. The efficiency curves of the FC and of the absorption chiller will be reported in section 5, together with the other modeling results. (a) Boiler

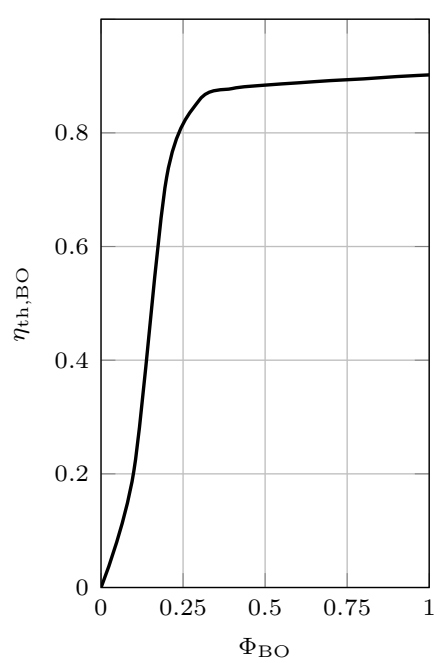

(b) Mechanical chiller

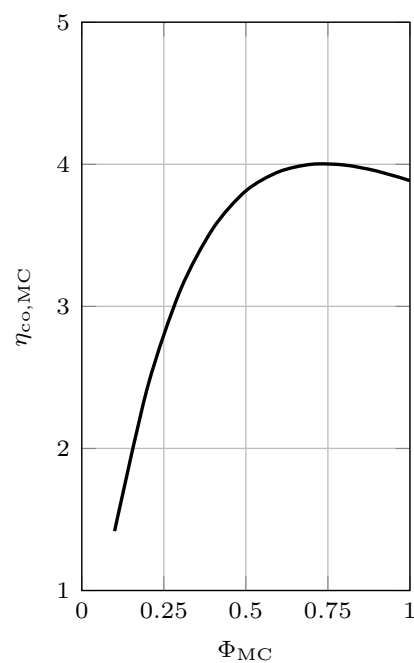

Figure 7: Efficiency curve of the water boiler (a) and coefficient of performance curve of the mechanical chiller (b) as functions of the energy converter set point.

\subsection{Determination of the control strategy}

The operating efficiency of any power plant is largely determined by its control strategy, as highlighted, for instance, in $[12,56,58,82-86]$. Thereafter, we compare the performance of the different configurations assuming a smart management policy that minimizes the total energy cost. The control strategy is 
determined through the optimization methodology introduced in [56], and further developed in [57-59]. Such a methodology minimizes a prescribed objective function on a daily basis accounting for: (i) the design performance of all the subsystems; (ii) the derating of the performance at part load; (iii) the effects of environmental conditions; (iv) energy demand and costs as functions of time; (v) maintenance, and cold start costs; (vi) constraints related to the dynamic behavior of the equipment, such as the minimum time interval between two consecutive starts or shutdowns.

All the energy converters are modeled as black-boxes, through their efficiency curves as functions of the set point and the environmental conditions. Specifically, the power output of the $j$-th subsystem at time $t$ is calculated as:

$$
\dot{P}_{i, j}(t)=\Phi_{j}(t) \dot{P}_{i, j}^{\text {nom }} \alpha_{i, j}(t),
$$

where $\Phi_{j}(t)$ is the set point, $\dot{P}_{i, j}^{\text {nom }}$ is the design power, and $\alpha_{i, j}(t)$ is the power derating coefficient, that is function of the environmental temperature, pressure, and altitude. Note that $i$ can assume a value in the set [el; th; co], representing respectively electric, heating, and cooling power output. The corresponding required input power is:

$$
\dot{U}_{j}(t)=\frac{\dot{P}_{i, j}(t)}{\eta_{i, j}\left(\Phi_{j}(t)\right) \beta_{i, j}(t)}
$$

where $\eta_{i, j}\left(\Phi_{j}(t)\right)$ is the efficiency, and $\beta_{i, j}(t)$ is the efficiency derating coefficient, that is function of the environmental temperature, pressure, and altitude. Note that the problem is nonlinear, since the efficiency is a function of $\Phi_{j}(t)$.

Economic optimization is performed through the following objective function:

$$
\begin{array}{r}
G_{\text {Cost }}=\sum_{t=1}^{8760} C_{f}(t, s(t))+C_{m}(t, s(t))+ \\
+C_{s}(t, s(t))-R(t, s(t)),
\end{array}
$$

being $t$ the time interval, $C_{f}$ the cost of fuel, $C_{m}$ the maintenance cost, $C_{s}$ the cold-start cost, and $R$ the revenue/cost yielding from the electricity exchanged with the grid. Costs are functions of the time interval and the plant state (i.e. the set point of the subsystems) $s(t)$.

Equation (10) is subject to constraints related to the energy flows and to the dynamic behavior of the plant subsystems. The thermal power balance for each time interval reads:

$$
\dot{P}_{\mathrm{th}}^{\mathrm{us}}(t)-\sum_{j} \dot{P}_{\mathrm{th}, j}(t)+\dot{P}_{\mathrm{th}, \mathrm{st}}(t) \geq 0 \quad \forall t,
$$

where $\dot{P}_{\mathrm{th}}^{\mathrm{us}}(t)$ is the thermal power demand, $\sum_{j} \dot{P}_{\mathrm{th}, j}(t)$ is the heating power produced by the energy converters within the plant, and $\dot{P}_{\mathrm{th}, \mathrm{st}}(t)$ is the the thermal power of the heat storage. Note that, $\dot{P}_{\mathrm{th}}^{\mathrm{US}}(t)$ and $\sum_{j} \dot{P}_{\mathrm{th}, j}(t)$ are positive, while $\dot{P}_{\mathrm{th}, \mathrm{st}}(t)$ is positive when the system is storing energy and negative when it is releasing the heat. The cooling power balance for each time interval reads:

$$
\dot{P}_{\mathrm{co}}^{\mathrm{us}}(t)-\sum_{j} \dot{P}_{\mathrm{co}, j}(t) \geq 0 \quad \forall t
$$

being $\dot{P}_{\mathrm{co}}^{\mathrm{US}}(t)$ and $\sum_{j} \dot{P}_{\mathrm{co}, j}(t)$ the cooling power demand and production respectively. The following system of equations represents the constraint related to the dynamic behavior of the subsystems:

$$
\left\{\begin{array}{l}
\text { if } \tau_{j}(t)<\tau_{j}^{*} \text { and } \Phi_{j}(t-1)>0 \rightarrow \Phi_{j}(t)>0 \\
\text { if } \theta_{j}(t)<\theta_{j}^{*} \text { and } \Phi_{j}(t-1)=0 \rightarrow \Phi_{j}(t)=0
\end{array}\right.
$$

where $t$ is the time interval, $\Phi_{j}(t)$ is the set point of the $j$-th energy system, $\tau_{j}$ is the time spent since the last cold start, and $\tau_{j}^{*}$ is the minimum time interval between two consecutive cold starts. Similarly, $\theta_{j}(t)$ is the time spent since the last shut down and $\theta_{j}^{*}$ is the minimum time interval between two consecutive shut downs.

Equation (10) is discretized with respect to the plant state and in time, and the problem is represented as a weighted and oriented graph. The optimal control strategy is determined by seeking for the shortest path across the graph. The reader can refer to [56-59] for more details on the optimization methodology.

\subsection{Economic analysis}

Thanks to the control strategy optimization we determine the set point of each component of the energy system for each time-step. Then, we can calculate the cash-flow associated to the energy system, that is $C=\min \left(G_{\text {Cost }}\right)$. As a consequence, we don not need to include the investment cost in the cost of energy, as usually done considering the Levelized Cost Of Energy (LCOE). In fact, we can compare the investment cost directly with the cash flow of the energy system. Also, we avoid assuming the utilization factor, as usually done when considering the LCOE analysis.

As a consequence, we can evaluate the economic feasibility of Case A and Case B power plants through the pay-back period (i.e.the time in which the total savings are equal to the initial investment), calculated as:

$$
\mathrm{PBP}=\frac{I_{\mathrm{add}}}{C_{\mathrm{ref}}-C},
$$

where $I_{\text {add }}$ is the difference between the capital cost of the considered case and of the reference scenario, $C_{\text {ref }}$ is the annual energy cost of the reference case and $C$ is the annual cost of the analyzed case. For Case A, $I_{\text {add }}$ accounts only for the cost of the PEMFC based CHP system, while for Case B it also considers the cost of the absorption chiller. In fact, the mechanical chiller, the water boiler and the thermal storage are present also in the reference case and do not represent an additional investment.

We consider an investment of $2000 € / \mathrm{kW}$ for the automotive derivative PEMFC CHP plant, according to the European project AutoRE target $[50,51]$. Moreover, for the half-effect absorption chiller we consider a unit cost of $1200 € / \mathrm{kW}$. This is a typical cost for double-effect absorption chillers. Half-effect machines are not in the commercial phase, however we assume that the cost of such devices is similar to that of double-effect absorption chillers, given the structure with three pressure levels that implies two generators, two absorbers, two pumps, and two solution heat exchangers. 


\subsection{Environmental impact evaluation}

Carbon dioxide emissions are calculated through the following equation,

$$
m_{\mathrm{CO}_{2}}=\sum_{i=1}^{N_{\text {fuel }}}\left(m_{i} k_{i}\right)+E_{\text {grid }} k_{\text {grid }}
$$

where $N_{\text {fuel }}$ is the number of different fuels utilized in the plant, $m_{i}$ is the mass of the $i-$ th fuel, $k_{i}$ is its $\mathrm{CO}_{2}$ emission factor, $E_{\text {grid }}$ is the electrical energy exchanged with the grid, and $k_{\text {grid }}$ is the carbon dioxide intensity of the grid.

\subsection{Energy demand}

The US Department of Energy (DOE) published the "commercial reference buildings" database [87], where the hourly electricity, heat, and chilling energy demand profiles are reported for 16 different commercial reference buildings. Each structure is situated in more than 1000 locations (that represents different climatic conditions) in all the US. Data are available for an entire year.

The International Energy Agency (IEA) divided the entire world in 6 different climatic zones [36, 88]: (i) cold climate, (ii) heating based climate; (iii) combined climate; (iv) moderate climate; (v) cooling based climate; (vi) hot climate. Such a classification relies on the yearly Heating Degrees Days (HDD) and Cooling Degrees Days (CDD), as summarized in Table 3. Note that the reference temperature is $18^{\circ} \mathrm{C}$ for both $\mathrm{CDD}$ and HDD.

\begin{tabular}{l|ccc}
\hline \hline Climatic Zone & $\operatorname{HDD}\left[{ }^{\circ} \mathrm{C}\right]$ & $\mathrm{CDD}\left[{ }^{\circ} \mathrm{C}\right]$ & City \\
\hline Cold & $\geq 2000$ & $\leq 500$ & Warsaw (Poland) \\
Heating Based & $\geq 2000$ & {$[500,1000]$} & Milan (Italy) \\
Moderate & $\leq 2000$ & $\leq 1000$ & Malaga (Spain) \\
Chilling Based & {$[1000,2000]$} & $\geq 1000$ & Athens (Greece) \\
Hot & $\leq 1000$ & $\geq 1000$ & Larnaca (Cyprus) \\
\hline \hline
\end{tabular}

Table 3: Heating and cooling degrees days and representative city for each IEA climatic zone [88].

For clarity, we report in Table 3 an example of a European city for each climatic zone. Note that combined climate is not representative of any European territory, therefore we decided to neglect it.

The residential building that we consider is composed by about 10-15 apartments. Peak and average electrical, thermal, and chilling demands are represented in Figure 8, for each climatic zone. The electricity load is only marginally influenced by the location of the plant. On the contrary, heat and cooling demands are significantly influenced by the climatic zone. By comparing Table 3 and Figure 8, we note that for thermal and cooling demands, the difference between average and peak demand rises as the degrees day increase.

We sithetically characterize the energy demand through the cooling to power ratio $\Theta$, defined as:

$$
\Theta=\frac{E_{\mathrm{ch}}}{E_{\mathrm{el}}},
$$

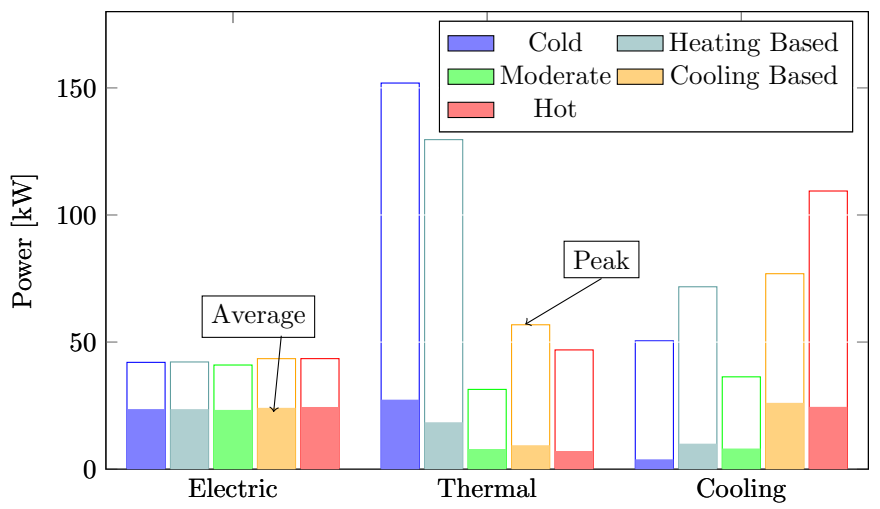

Figure 8: Average and peak electricity demand for all the combinations of climatic condition and building energy demands.

and the heat to power ratio $\Omega$ :

$$
\Omega=\frac{E_{\mathrm{th}}}{E_{\mathrm{el}}} .
$$

Therein $E_{\mathrm{ch}}, E_{\mathrm{th}}$, and $E_{\mathrm{el}}$ are the total early consumption of cooling, heating, and electrical energy.

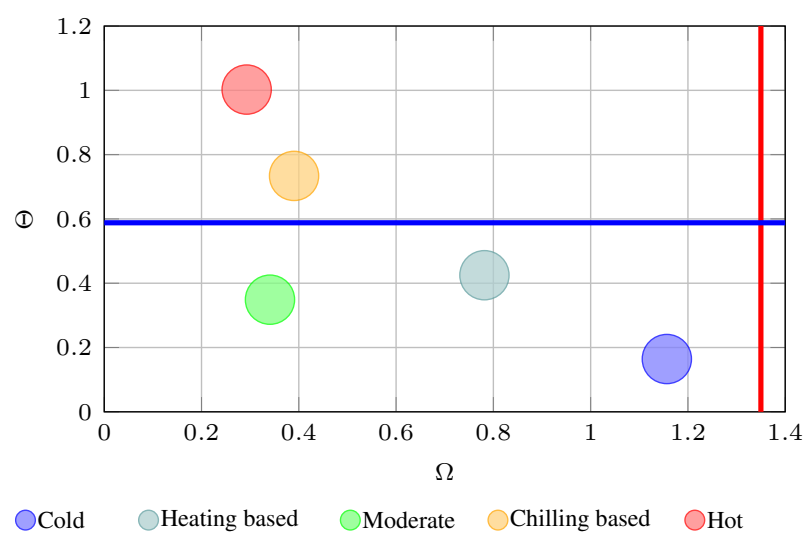

Figure 9: Cooling and heat to power ratios of the energy scenarios studied. The red vertical line is the heat to power ratio of the CHP system, calculated with nominal powers. The blue horizontal line is the cooling to power ratio, calculated with nominal power of the fuel cell and of the absorption chiller.

Figure 9 classifies the considered case studies with respect to $\Theta$ and $\Omega$. The red vertical line represents the ratio between the nominal thermal and electrical power of the CHP system. Since $\Theta$ is below that boundary for all the climates, following the thermal tracking plant control strategy would result in a large import of electricity, in particular for moderate, chilling based, and hot climatic zones. On the other hand, through the electrical tracking a significant amount of heat would be wasted. Thereafter, there is a large opportunity to exploit the waste heat through thermally driven refrigeration (as in Case B), to boost the CHP performance.

Similarly, the blue horizontal line in Figure 9 represents the ratio between the nominal cooling power of the absorption chiller and the nominal power of the CHP. We note that the absorption chiller can deliver the required cooling energy for the cold, heating based, and moderate climate. On the contrary, for 
cooling based and hot conditions an integration from the mechanical chiller is required.

Figure 9 also shows that $\Theta$ and $\Omega$ are strongly influenced by the climatic zone. In fact, moving from hot to cold climate $\Theta$ decreases, while $\Omega$ increases. All the cases are almost arranged along a straight line with negative slope except for the moderate climate that is characterized by very low thermal and cooling demands (see Figure 8).

Finally, it is worth to note that the yearly environmental temperature profile is necessary to evaluate the performance derating of the absorption chiller. Such a value is retrieved from the European commission joint research center [89] for each city reported in Table 3 .

\subsection{Energy prices and grid emission factors}

The optimization methodology requires the prices of the energy vectors entering and exiting the power plant. Electricity is the only form of energy product of the CHCP plant that can be acquired from or sold in the external grid. However, we consider that the electricity sold to the grid is not remunerated. Such an assumption is necessary in order to perform a general study. In fact, electricity remuneration from small Distributed Generation (DG) plants, largely relies on national subsidiary mechanisms. We underline that this is a conservative assumption that underestimates the economic profitability of the proposed power plant. Natural gas is the other possible input energy source to the plant.

Electricity and NG prices are retrieved from the Eurostat database [90], assuming an average value between the two semesters of 2016 for house-holds consumers category. All taxes and levies are included. Tables 4 and 5 report all the unit energy costs as a function of the total yearly consumption. We assume constant unit costs on a daily and yearly basis.

\begin{tabular}{c|lllll}
\hline \hline \multicolumn{5}{c}{ Electricity [c€/kWh] } \\
\hline & Band & Band & Band & Band & Band \\
& DA & DB & DC & DD & DE \\
\hline Poland & 16.4 & 14.2 & 13.4 & 12.8 & 12.7 \\
Italy & 31.6 & 21.7 & 23.8 & 27.6 & 27.5 \\
Spain & 51.3 & 27.3 & 22.3 & 19.6 & 17.2 \\
Greece & 23.4 & 17.2 & 17.2 & 17.8 & 19.0 \\
Cyprus & 19.1 & 15.7 & 15.7 & 15.4 & 14.8 \\
EU $_{28}$ & 33.3 & 22.6 & 20.5 & 19.4 & 18.5 \\
\hline \hline
\end{tabular}

Table 4: electrical energy costs utilized for the different scenarios [90]. Band DA stands for yearly electrical energy consumption Cons. ${ }^{\text {el. }}<10^{3} \mathrm{kWh}$; Band DB for $10^{3} \mathrm{kWh}<$ Cons. ${ }^{\text {el. }}<2.5 \times 10^{3} \mathrm{kWh}$; Band DC for $2.5 \times 10^{3} \mathrm{kWh}<$ Cons. ${ }^{\text {el. }}<5 \times 10^{3} \mathrm{kWh}$; Band DD for $5 \times 10^{3} \mathrm{kWh}^{2}$ Cons. $^{\text {el. }}<1.5 \times$ $10^{4} \mathrm{kWh}$; Band DE for Cons. ${ }^{\text {el. }}>1.5 \times 10^{4} \mathrm{kWh}$.

To compare the environmental performance of the several cases we consider the natural gas carbon dioxide emission factor $k_{\mathrm{NG}}=0.200 \mathrm{~kg} / \mathrm{kWh}$ [91]. Table 6 summarizes the carbon dioxide emission factors of the electricity available from the distribution grid for the different national scenarios. Data are retrieved from [92].

Note that assuming the energy consumption retrieved for US buildings [87] valid in a European energy context [90, 92]

\begin{tabular}{c|lll}
\hline \hline \multicolumn{4}{|c}{ Natural Gas [€/GJ] } \\
\hline & Band & Band & Band \\
& D1 & D2 & D3 \\
\hline Poland & 15.2 & 11.6 & 10.4 \\
Italy & 30.2 & 21.8 & 19.6 \\
Spain & 27.1 & 21.3 & 15.9 \\
Greece & 23.6 & 16.9 & 15.1 \\
Cyprus & 8.99 & 8.84 & 8.80 \\
EU $_{28}$ & 26.8 & 17.5 & 15.6 \\
\hline \hline
\end{tabular}

Table 5: Natural Gas prices utilized for the different scenarios [90]. Band D1 stands for yearly natural gas consumption Cons. ${ }^{\mathrm{NG}}<20 \mathrm{GJ}$; Band D2 for $20 \mathrm{GJ}<$ Cons. $^{\mathrm{NG}}<200 \mathrm{GJ}$; Band D3 for Cons. ${ }^{\mathrm{NG}}>200 \mathrm{GJ}$.

\begin{tabular}{c|c}
\hline \hline Scenario & $k_{\text {grid }}[\mathrm{kg} / \mathrm{kWh}]$ \\
\hline Poland & 0.767 \\
Italy & 0.980 \\
Spain & 0.431 \\
Greece & 0.810 \\
Cyprus & 0.341 \\
EU $_{28}$ & 0.447 \\
\hline \hline
\end{tabular}

Table 6: Carbon dioxide emission factors of the electricity available from the distribution grid for the several national scenario analyzed, data are retrieved from [92].

entails that the buildings occupants have similar behavior in the two geographic regions. Moreover, we implicitly consider the same technological level in home appliances and building construction. Such assumptions can be considered reasonable, given the comparable economic development level of these two regions.

\section{Results and discussion}

\subsection{Power Plant Modeling}

\subsubsection{CHP Plant}

Results obtained from the sensitivity analysis to $\Phi_{\mathrm{CHP}}$ of the CHP plant are reported in Figure 10. Note that the minimum possible set point is $\Phi_{\mathrm{CHP}}^{\mathrm{min}}=55.3 \%$, according to limitations of the fuel processor, verified in experimental data of a real CHP plant under development within a European project [50, 51].

We note that the overall electrical efficiency ranges between $36.1 \%$ and $40.0 \%$, as a function of the set point, reaching its maximum at part load due to the fuel cell polarization curve $[13,14,53]$.

In this model we assume that the natural gas from the distribution grid is already at 12 bar (or more), that is the operating pressure of the fuel processor. Considering the distribution pressure equal to 1 bar would reduce the electrical efficiency (due to the NG compressor work) by $1.19 \%$. In real conditions $\mathrm{NG}$ is delivered with a pressure 1 bar $<p^{\mathrm{NG}}<12$ bar, leading to an efficiency close to that here considered.

Thermal efficiency (Figure 10 (b)) values are in the range $49.4 \%<\eta_{\text {th,CHP }}<60.2 \%$. The efficiency increases increasing the set point, as a consequence of the reduction of $\eta_{\mathrm{el}, \mathrm{CHP}}$. 
(a) Electrical efficiency
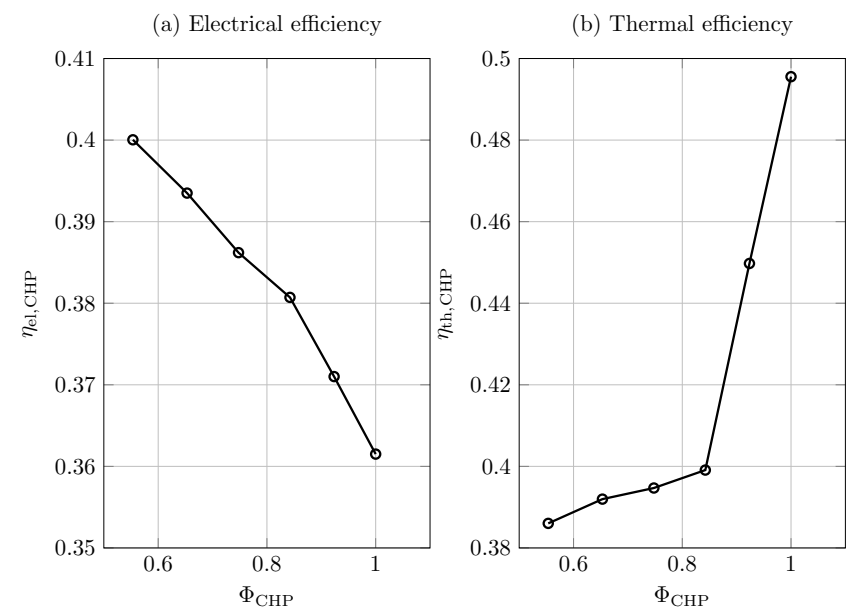

Figure 10: Efficiency of the CHP power plant as functions of the power set point: (a) Overall electrical efficiency; (b) Thermal efficiency.

Such a phenomenon is more evident for $\Phi_{\mathrm{CHP}}>0.800$. In this working regimen the electrical efficiency has a sharp decrease, due to ohmic and concentration losses.

The water temperature at the inlet of the CHP plant, (i.e. coming from the thermal storage) is set to $60^{\circ} \mathrm{C}$, in line with the typical return temperature of domestic heating applications. Also the half-effect absorption chiller releases water at the same temperature. The resulting mass flow rate and cogenerated water temperature are reported in Figure 11 as functions of $\Phi_{\mathrm{CHP}}$.

(a) Cogeneration mass flow rate
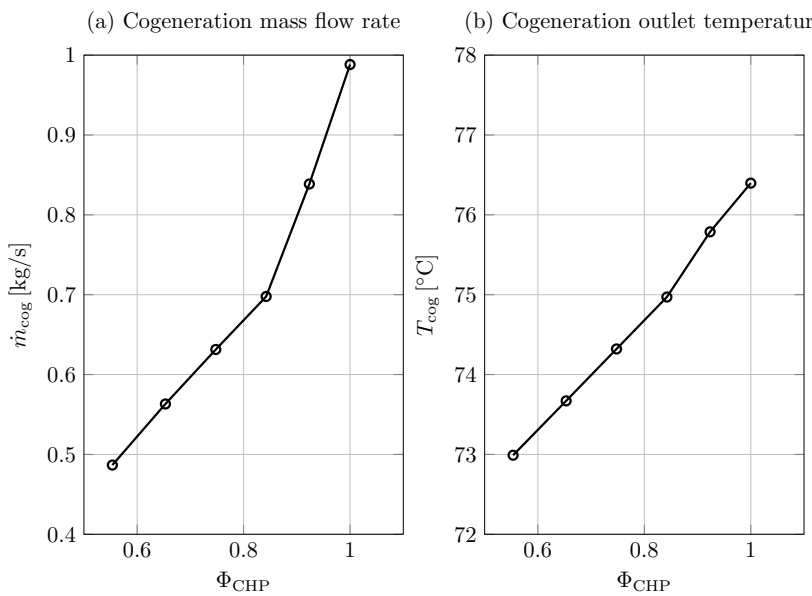

Figure 11: Cogenerated outlet flow characteristics: (a) mass flow rate (b) temperature.

The temperature values reported in Figure 11 are in line with domestic heating purposes. In fact, such applications require in most common appliances hot water at a temperature in the range $\left[45^{\circ} \mathrm{C}-75^{\circ} \mathrm{C}\right]$. Moreover, the half-effect absorption chiller operates with a temperature of the generators equal to $70^{\circ} \mathrm{C}$.

\subsubsection{Absorption Chiller}

Figure 12 shows that the COP varies in the range [0.400, $0.430]$ as a function of $\Phi_{\mathrm{AC}}$. The COP variation is moderate be-

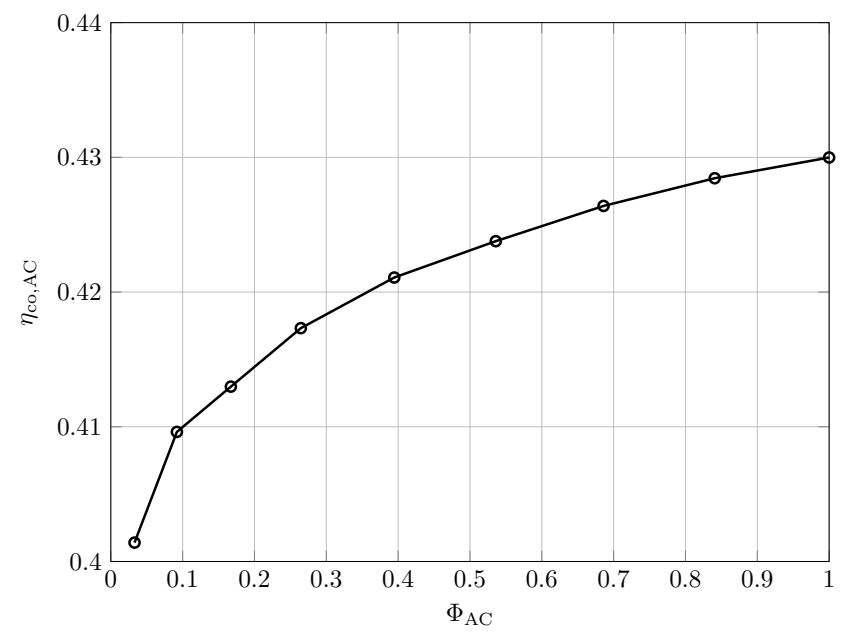

Figure 12: Half-effect absorption chiller coefficient of performance as a function of the set point.

cause the generators temperature is kept constant while varying $\Phi_{\text {AC }}$. However, we note that the obtained nominal efficiency is in line with several results available in literature $[52,76]$.

Moreover, we comment that the COP value of the half effect absorption chiller it is considerably lower than the COP of a single effect absorption chiller or of a vapor compression chiller. However, we comment that only with the half-effect absorption chiller is possible to generate cooling energy effect from the low temperature heat of a PEMFC CHP system. As a consequence, we are able to recover an amount of heat that would otherwise be wasted in the environment. Thus, the utilization of absorption chillers reduces the cost of the rejection of heat to the environment.

Environmental conditions also significantly influence the power and COP of the absorption chiller as evidenced in Figure 13. In this case, the most relevant environmental variable is the temperature $\left(T_{\text {env }}\right)$. In fact, it influences both the condenser pressure and the $\mathrm{LiBr}$ concentration in the the low pressure absorber (absorber 1). These two parameters affects the refrigerant separation in the generators and the cooling power and the coefficient of performance of the device.

For temperatures higher than $30^{\circ} \mathrm{C}$ the maximum power is dramatically reduced. At $35^{\circ} \mathrm{C}$ the maximum cooling power is halved compared to $T_{\text {env }}=30^{\circ} \mathrm{C}$. For $20^{\circ} \mathrm{C}<T_{\text {env }}<30^{\circ} \mathrm{C}$ the nominal cooling power is almost constant.

If temperature is increased from $20^{\circ} \mathrm{C}$ to $35^{\circ} \mathrm{C}$, the $\mathrm{COP}$ is reduced by $10 \%$.

Note that the the absorbers and condeser temperatures are $5{ }^{\circ} \mathrm{C}$ higher than $T_{\text {env }}$ reported in Figure 13 (see section 3 ).

\subsection{Economic and environmental performance in realistic sce- narios}

Here, we report the most representative and synthetic parameters, resulting from the $\mathrm{CHCP}$ plant simulation in real energy management scenarios. Specifically, we focus on the yearly total energy cost (accounting for all energy vectors), together with the annual total $\mathrm{CO}_{2}$ emissions, and finally the Utilization 

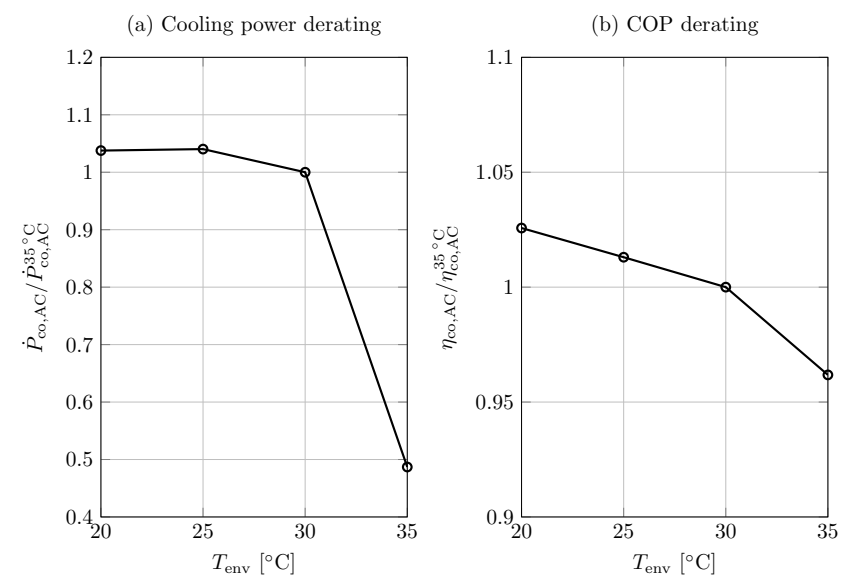

Figure 13: Half-effect absorption chiller power and COP derating, as functions of environmental temperature. Nominal conditions for $T_{\mathrm{env}}=35^{\circ} \mathrm{C}$. Absorbers and condenser temperatures are $5{ }^{\circ} \mathrm{C}$ higher than $T_{\text {env }}$.

Factors (UFs) of the components of the power plant. Figure 14 reports the results obtained considering the real energy context of each country representative of a climatic zone (see Tables 3, 4, 5, and 6). Figure 15 is obtained considering the average European energy context (see Tables 4, 5, and 6). Such a twofold analysis is necessary because, in Figure 14, we can analyze a real example of the adoption of a distributed generation system. On the contrary Figure 15 reports general results, valid for all Europe.

Both economical and environmental aspects are relevant for a distributed generation power plant. In fact, the economical convenience drives the investments towards innovative energy systems. However, our aim is to propose a CHCP system that can be effective both in economic and environmental terms.

Figure 14 (a) highlights the drastic cost reduction associated to the CHP plant (Case A) with respect to the reference scenario. Such advantages are further boosted when the absorption chiller is used (Case B). The economic savings are a function of the climatic zone and of the energy context, that, in turn, influence the energy loads and prices. For Case A the cost reductions, with respect to the reference case, are between $9.66 \mathrm{k} €$ and $33.9 \mathrm{k} €$ per year. On the other hand, for Case B the cost reduction varies in the range [12.8 k€, $37.2 \mathrm{k} €]$ with respect to the reference scenario. As expected, Case B always reduces the energy cost compared to Case A. In particular, the hot climate yields the most relevant difference with a $8.30 \%$ reduction of the energy cost.

Case $\mathrm{A}$ reduces the $\mathrm{CO}_{2}$ emission for all the climates except for the moderate one (Figure 14 (b)). In the latter case, $\mathrm{CO}_{2}$ emissions are increased by $17.6 \%$. In all the other climates the $\mathrm{CO}_{2}$ emissions reductions, with respect to the reference case, are between $16.0 \mathrm{t}$ and $164 \mathrm{t}$ per year. Case $\mathrm{B}$ further reduces the carbon dioxide emissions. Specifically, $\mathrm{CO}_{2}$ reduction ranges between $-8.89 \mathrm{t}$ (for moderate climate) and $171 \mathrm{t}$ (for cold climate). Case $\mathrm{B}$ always reduces carbon emissions with respect to case A.

The utilization factor of the CHP system is always higher than $50 \%$, except for the moderate climatic zone. In fact, in such a climate the thermal and cooling loads are relatively low, leading to poor utilization of the CHP system. This, together with the low grid $\mathrm{CO}_{2}$ emission factor of Spain (see Table 6), leads also to the negative environmental performance of the power plant in the moderate climatic zone.

Moreover, the adoption of the absorption chiller lowers the utilization factor of the FC because it reduces the electrical demand while increasing the recovery of the waste heat from the prime mover. Thereafter, the same useful effect is obtained with less fuel and power plant utilization.

Finally, we note that the CHP utilization factor rises increasing the cooling degrees days, that is passing from cold to hot climatic zones.

Figure 14 (d) evidences that the usage of the CHP power plant dramatically reduces the boiler utilization factor. In fact, such a component is practically useless if a distributed generation plant is utilized, for all climatic zones except for colder ones.

In Table 7 we present the global performance of the different power plant configurations in the case of hot climate and considering the real energy context.

\begin{tabular}{l|ccc}
\hline \hline & Reference & Case A & Case B \\
\hline Total energy cost $[\mathrm{k} €]$ & 49.7 & 27.5 & 23.4 \\
$\mathrm{CO}_{2}$ emissions [t] & 274 & 168 & 134 \\
$\mathrm{CHP}$ utilization factor & $/$ & 0.714 & 0.635 \\
Boiler utilization factor & 0.173 & 0.000 & 0.000 \\
\hline \hline
\end{tabular}

Table 7: Global performance of the different power plant configurations in the case of hot climate and considering the real energy context.

The results reported in Figure 14 combines the different climatic conditions to the national energy costs. However, the same climate might apply different country. Figure 15 is more general and allows studying the proposed energy systems in a European energy context. Specifically, given the same energy costs, we can dissect the influence of the climatic conditions on the general results. We observe again that Case A significantly reduces the energy cost with respect to the reference case (see Figure 15 (a)). Specifically, the revenues (or equivalently avoided costs) range from $13.0 \mathrm{k} €$ and $18.8 \mathrm{k} €$. Using the absorption chiller further reduces the costs by $16.1 \mathrm{k} €$ in the worst case (i.e. moderate climate), and by $22.7 \mathrm{k} €$ in best case (i.e. hot climate).

Figure 15 (b) highlight that, in the average European energy scenario, Case $\mathrm{B}$ always reduces the $\mathrm{CO}_{2}$ emissions irrespective of the climatic condition. On the contrary, Case A increases carbon dioxide emissions for hot climates. Using the CHP plant together with the mechanical chiller we obtain $\mathrm{CO}_{2}$ emissions reductions between $-2.34 \mathrm{t}$ and $30.1 \mathrm{t}$ per year. The usage of the absorption chiller increases environmental benefits, with $\mathrm{CO}_{2}$ emissions reductions in the range [14.7 t , 34.6 t].

We comment that in Case A and Case B the total energy cost is lower than the Reference case total energy cost for every climatic condition and energy context analyzed, as a consequence of the CHP system adoption. Such a result is strictly connected to the possibility to recover heat in the CHP system 
(a) Total energy cost

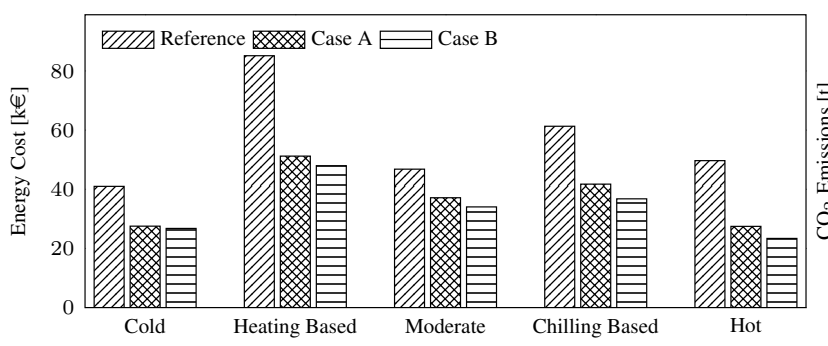

(c) CHP Utilization Factor

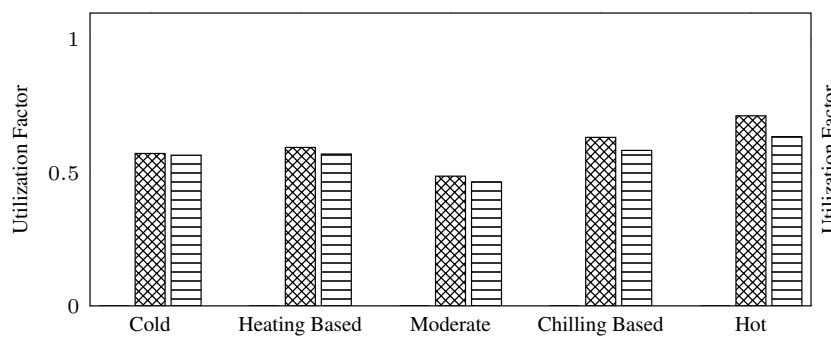

(b) $\mathrm{CO}_{2}$ Emissions

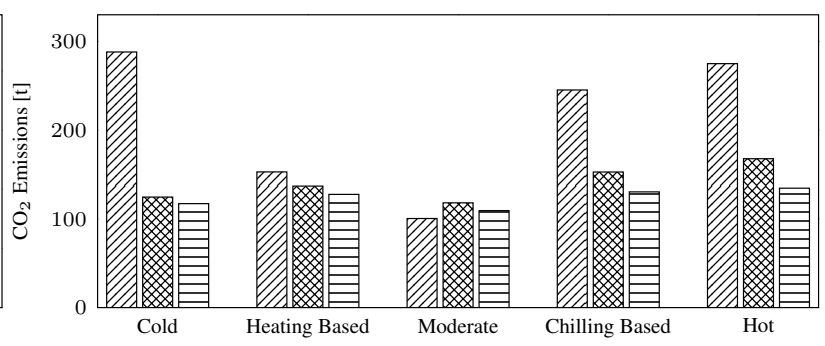

(d) Boiler Utilization Factor

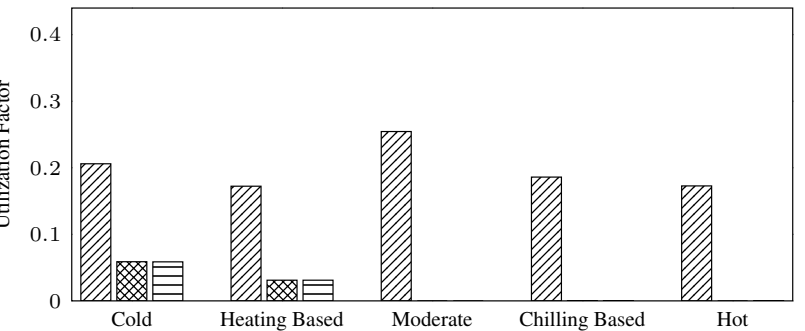

Figure 14: Global performance of the different power plant configurations within the real energy context: (a) total energy cost; (b) $\mathrm{CO}_{2}$ emissions; (c) $\mathrm{CHP}$ utilization factor; (d) Boiler utilization factor.

(a) Total energy cost

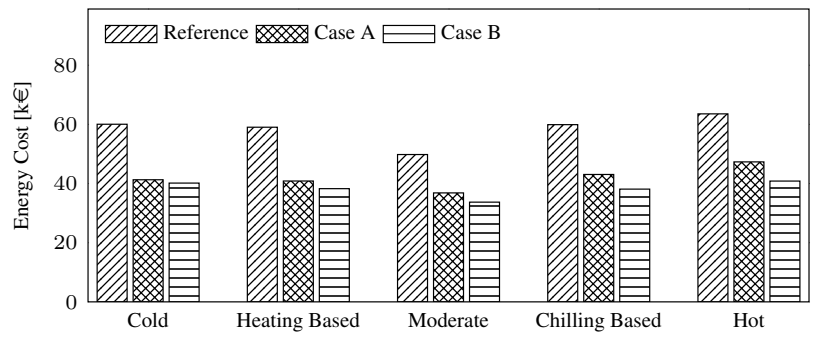

(c) CHP Utilization Factor

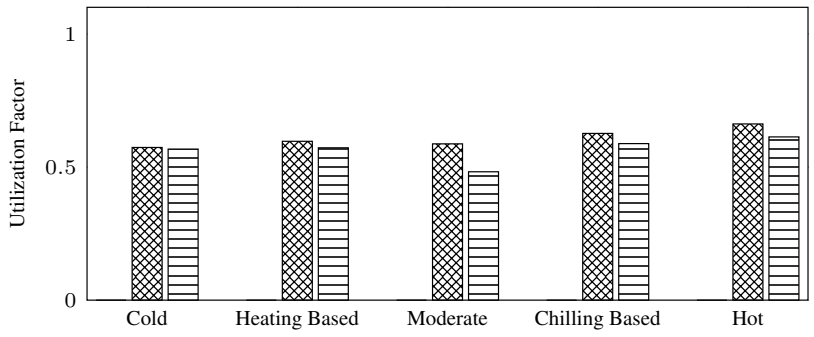

(b) $\mathrm{CO}_{2}$ Emissions

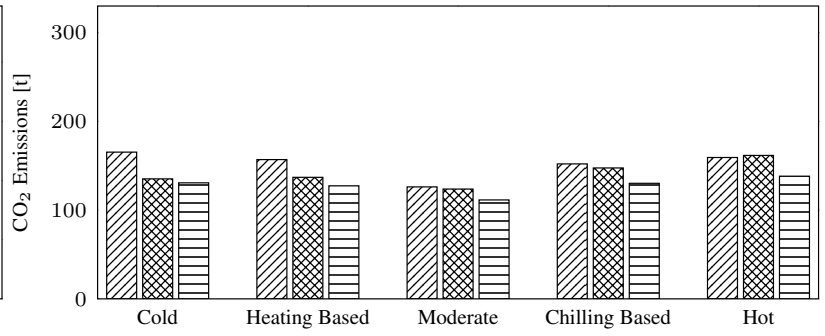

(d) Boiler Utilization Factor

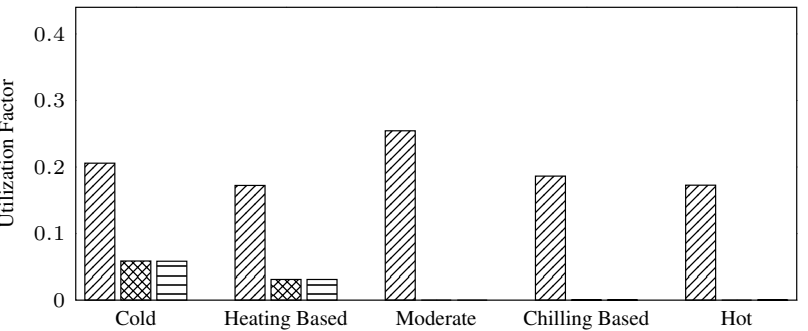

Figure 15: Global performance of the different power plant configurations within the mean European energy context: (a) total energy cost; (b) $\mathrm{CO}_{2}$ emissions; (c) CHP utilization factor; (d) Boiler utilization factor.

while producing electricity. Accordingly, the cost of natural gas necessary to satisfy the thermal energy demand is drastically reduced. Moreover, the relatively high efficiency, in particular at part load, of the fuel cell system makes the cost of electricity produced competitive with that of the electricity bought from the grid. In fact, considering $\eta_{\mathrm{el}, \mathrm{CHP}}=0.36$ the cost of NG to produce electricity with the CHP varies in the range $[8.8,19.6]$ $\mathrm{c} € / \mathrm{kWh}_{\mathrm{el}}$ as function of the NG prices in Table 5, considering that the consumption of NG is larger than $200 \mathrm{GJ} /$ year. Such costs are lower, or at least comparable with those reported in Table 4 for electricity from the grid.
In this work we are investigating the influence of the introduction of an absorption chiller in a CHP system. The importance of such a device is strictly related to the cooling loads. For this reason, we expect a seasonal trend in the impact on global parameters. Figure 16 (a) reports, the total energy cost associated to the different power plant configurations on a monthly basis for the hot climate case and assuming the energy costs and efficiencies of Cyprus. We comment that, irrespective of the energy system configuration, energy costs are higher in the hot months, due to the higher cooling demand. In addition, the power plant accounting for the absorption chiller has always the 
best economic performance. Similar trends are observed also for chilling based climate, considering Greek energy context.

To isolate the absorption chiller effect, we focus on the energy cost difference between the Case A and Case B (Figure 16 (b)). The savings, related to the thermally activated cooling machine, are minimum of in February $(0.259 \mathrm{k} €)$ and are maximized in August, reaching $0.486 \mathrm{k} €$. The absorption chiller reduces the energy cost also in winter months. This happens because in the hot climate a chilling load is always present, also during the cold months of the year [87].

Figure 17 represents the techno-economic performance of the different plant configurations by reporting the relative cost variation on the abscissa, the relative $\mathrm{CO}_{2}$ reduction on the vertical axis and the radius of the circles is proportional to the PBP, calculated as described in section 4.3.

Considering the real energy context (see Figure 17 (a)) we obtain, for the Case A, a pay back period comprised between 3 years for heating based climate and 11 years for moderate climate. Such a variation is mainly due to the different energy costs relative to the different countries. In fact, considering the average European energy context (Figure 17 (b)) the PBP varies in the range [6 years, 8 years] for Case A, demonstrating that NG and electricity unit costs dominates the PBP variation with respect to the climate. In Case B power plants $\mathrm{PBP}$ is almost always 1 year higher than the Case A situation. In fact, despite the higher economic savings (see Figures 14 and 15), the capital cost of the absorption chiller is dominant. We comment, however, that the cost of the absorption chillers is rapidly decreasing, as a result of the technology diffusion and mass production.

Herein, we make a conservative estimation of revenues and PBP. In fact, we do not remunerate the excess electricity and we discard incentives to distributed generation. Moreover, the high reduction of $\mathrm{CO}_{2}$ emissions, registered in most of the analyzed cases, could generate further subsidiary mechanisms.

Focusing on the real energy context (see Figure 17 (a)) we obtain a cost reduction between $20.6 \%$ and $44.7 \%$ for Case A, and in the range $[27.3 \%, 53.0 \%$ ] for Case B. In the same scenario $\mathrm{CO}_{2}$ reduction varies between $-17.6 \%$ and $56.8 \%$ using the mechanical chiller and in the range $[-8.85 \%, 59.3 \%]$ for the Case B. We comment that for every climatic zone the adoption of the absorption chiller improves both economic and environmental performance. In fact, in Figure 17 the spheres related to Case $\mathrm{B}$ are always in the north-east with respect to Case A. The negative value of $\mathrm{CO}_{2}$ emissions reduction registered for the moderate climatic condition in the real energy context is a consequence of the low thermal energy demand of the moderate climate (see the $\Omega$ ratio in Figure 9) and of the low grid electricity emission factor (see Table 6). On the other hand, the large $\mathrm{CO}_{2}$ emissions reduction associated to the cold climate (see Figure 17 (a)) is due to the high grid emission factor and high $\Omega$ ratio (see Table 6 and Figure 9). In Figure 17 (b) the cost reduction is between $25.6 \%$ and $31.26 \%$ for Case $\mathrm{A}$, and in the range [27.3\%, 53.0\%] for Case B. Moreover, the carbondioxide emissions varies from $-1.47 \%$ to $18.2 \%$ in Case A and from $11.6 \%$ to $20.9 \%$ in Case B. We note that the use of the absorption chiller allows a significant increase of the $\mathrm{CO}_{2}$ emis- sion reduction, especially for the minimum values. In fact, in Case $\mathrm{B}$ the lowest $\mathrm{CO}_{2}$ reduction is more than 13 percentage points higher, compared to the lower environmental performing situation in Case A. Finally, within the $\mathrm{EU}_{28}$ scenario and with the absorption chiller, a positive $\mathrm{CO}_{2}$ emissions reduction is achieved for all climatic zones. On the contrary, a positive cost reduction is registered for all power power plant configurations, in every climatic zone and in every energy context.

The energy context can influence economic and environmental performance also within the same climatic zone. For example, for case A combining hot climate and Cyprus energy costs yields the best economic performance, with a $44.7 \%$ cost reduction. However, in the $\mathrm{EU}_{28}$ scenario, the last cited case is the worst performing, accounting for the lowest cost reduction $(25.6 \%)$. Such a drastic difference is mainly related to the dramatically low natural gas price for hot climate reference country. In fact, the ratio between the mean NG price for Cyprus and for $\mathrm{EU}_{28}$ scenarios is $\overline{\operatorname{Cost}}_{\mathrm{NG}}^{\text {Cyprus }} / \overline{\mathrm{Cost}}_{\mathrm{NG}}^{\mathrm{EU}_{28}}=0.445$. Similarly, the $\mathrm{CO}_{2}$ reduction, in the real energy context, for the Case $\mathrm{A}$ in hot climate is of $39.0 \%$ while in the $\mathrm{EU}_{28}$ context such a variation is $-1.47 \%$. Such a behavior is surely related to the ratio between the Cyprus and the mean $\mathrm{EU}_{28} k_{\text {grid }}$ that is 0.763 .

Case B has an impressive performance for the hot climate and assuming the real energy context. In this case both cost and $\mathrm{CO}_{2}$ emissions reductions are greater than $50 \%(53.0 \%$ and $51.1 \%$, respectively). This can be considered a promising application scenario for the coherence between economic and environmental drivers.

We conclude summarizing that, if the real energy context is evaluated, the adoption of the PEMFC based CHP power plant can be considered a viable solution, in economic and environmental terms, for all cases except the moderate climatic condition. When the CHCP system is used, $\mathrm{CO}_{2}$ emissions and costs reductions are improved for all cases. However, the moderate climate is still a non-fertile soil of application, mostly for the negative environmental performance. In this case the absorption chiller usage is not effective because the cooling energy demand is not consistent.

Considering the average European scenario, the CHP power plant can be considered a good option only for cold and heating based climatic zones. On the other hand, the adoption of the $\mathrm{CHCP}$ power plant is effective for all climatic conditions.

Finally, we note that the half-effect absorption chiller with a COP of 0.4 is competitive with the mechanical chiller with a COP of 4: despite the low utilization factor the investment cost is recovered in reasonable time. We comment that the halfeffect machine has a low COP, but it uses thermal energy that would be otherwise wasted in summer months. The mechanical chiller produces a cooling power 4 times higher than the input electrical power. But, the electricity has to be produced, or acquired. Moreover, the investment can be recovered relatively easily, also because the absorption chiller is not sized to cover the peak cooling demand, but its nominal power is $29.5 \mathrm{~kW}$. 

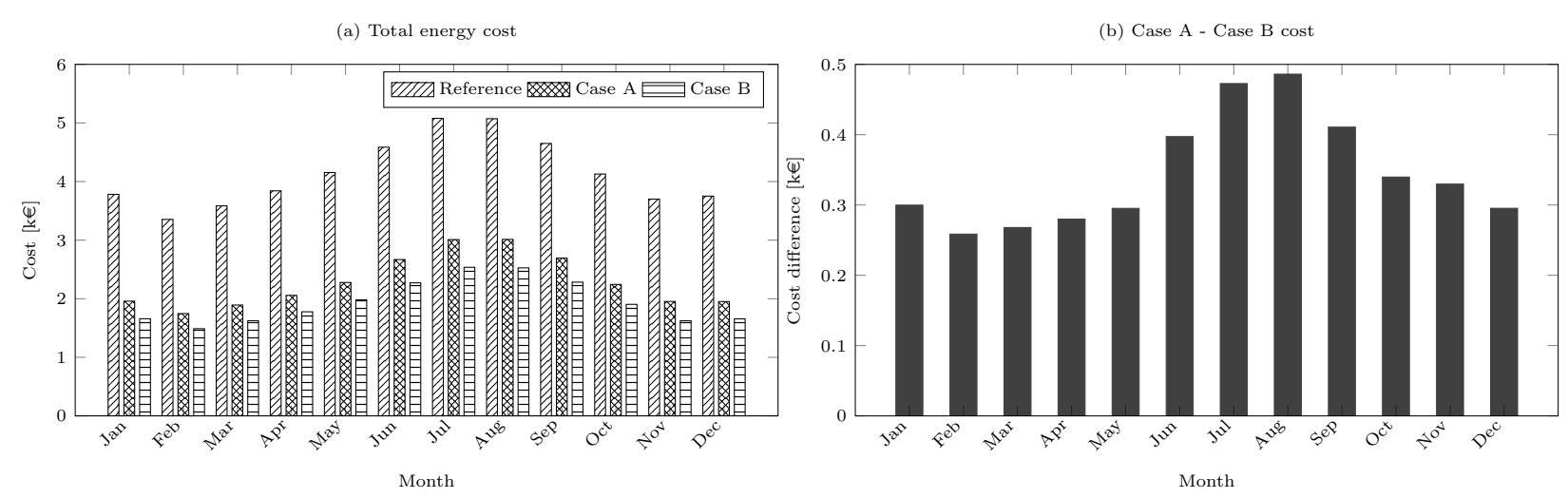

Figure 16: Global performance of the of the different power plant configurations on a monthly basis for the hot climatic condition within the real energy context: (a) total energy cost; (b) total energy cost difference between the FC_ and Case B plant configurations.
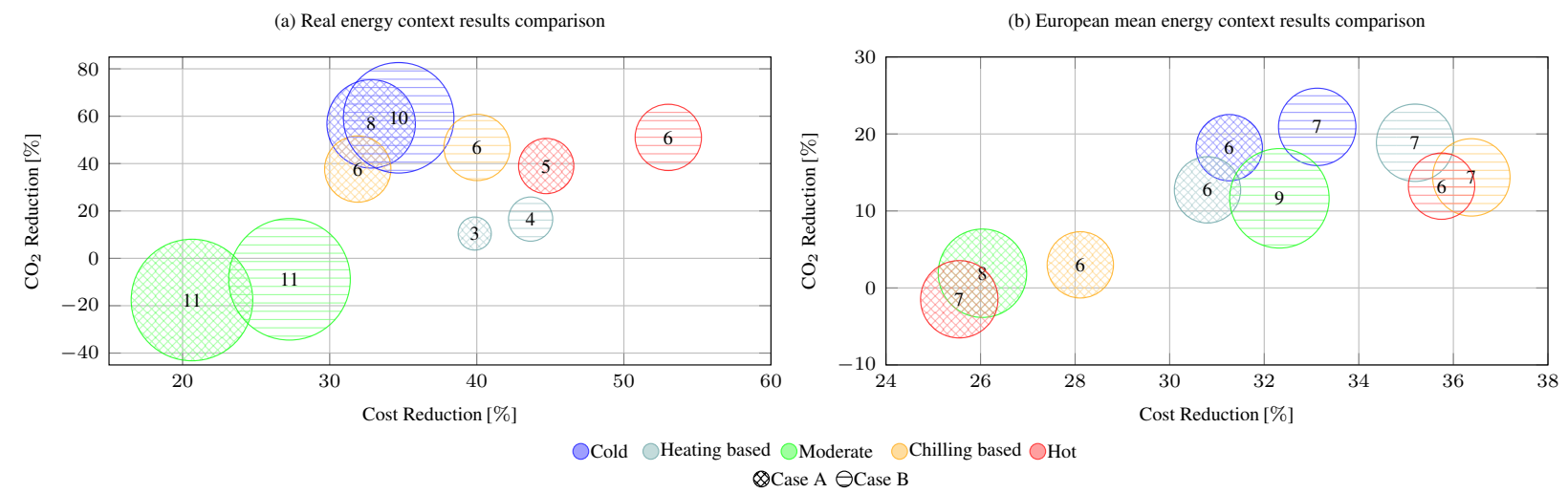

Figure 17: Comparison between the different climatic zones optimization results: (a) real energy context; (b) European mean energy context. The coordinates of the center of the circles represents the cost and the $\mathrm{CO}_{2}$ emissions reductions. The radius of the circles is proportional to the PBP. The value of the pay back period is also reported in the center of the circles.

\section{Conclusions}

In this paper we assess the environmental and economic impact of the integration of a half-effect absorption chiller in a $50 \mathrm{~kW}$ automotive derivative PEMFC based CHP plant. We first study the performance of the power plant components through thermo-chemical models. Specifically, we further refine a previously studied and validated model $[36,53-55]$ for the CHP plant, enhancing thermal integration for both heat of process and cogeneration. In addition, we develop a thermo-chemical model for the half-effect absorption chiller, following a validated methodology [52, 77].

These data are the main input for the second phase of the work, that is the techno-economic analysis. Therein, we assess the effective economic and environmental performance of the considered power plant in realistic scenarios.

We consider 5 different residential buildings energy demands, representative of 5 climates. We consider three different power plant configurations: (i) the reference case, that is separate production; (ii) the Case A, that is the cogeneration plant; (iii) the Case B which is the trigenerative plant. We also retrieve, from European statistics, natural gas and electricity costs, together with electrical grid $\mathrm{CO}_{2}$ emission factors characteristic of the several countries in which the typical cities are placed. Also a mean European value of such parameters is considered.

We always operate the power plants with an optimal control strategy, based on energy cost minimization. The optimization is performed through dynamic programming.

We evaluate the economic feasibility of the distributed generation power plants through the PBP and cash flow. Specifically, we assume additional investments equals to $2000 € / \mathrm{kW}$ for the automotive derivative PEMFC CHP plant and $1200 € / \mathrm{kW}$ for the half-effect absorption chiller.

The results show that the adoption of the absorption chiller in the distributed generation PEMFC based power plant is a key aspect that boosts environmental and economic benefits for all the energy contexts and in every climatic condition. Considering the average European energy context, thanks to the $\mathrm{CHCP}$ system $\mathrm{CO}_{2}$ emissions are reduced for all the considered climatic conditions. On the contrary for the CHP system such a behavior is not observed.

We comment that the climatic condition only marginally influence the economic feasibility of such energy systems while the energy context dominates it. On the contrary, the climatic conditions dominates the environmental performance of DG systems.

Due to the larger investment cost, Case B are always characterized by a longer PBP (generally 1 year more). However, 
Case B generates higher cash flows, resulting in a larger investment value after it has been recovered.

Finally, if the real energy context is considered, the adoption of the PEMFC based CHP power plant is a viable solution, in economic and environmental terms, for all cases except the moderate climatic condition. Also using the CHCP system, the moderate climate is still unfit for this application, having negative environmental performance. Climatic conditions with high cooling over power or heating over power ratios are the most attractive cases. For example at CHCP system in hot climate yields cost and $\mathrm{CO}_{2}$ emissions reductions both higher than $50 \%$.

For the average European scenario, the CHP power plant can be considered a good option only for cold and heating based climatic zones. On the contrary, Case B has a favorable performance in all the climatic conditions.

We also highlight that the adoption of the absorption chiller has a positive impact on the environmental performance of the FC based CHP plant. In fact, on average, case B further reduces the $\mathrm{CO}_{2}$ emission by $8.33 \%$ with respect to case $\mathrm{A}$. The most relevant improvement of the environmental performance is for the hot climate and the $\mathrm{EU}_{28}$ context. In this case, Case $\mathrm{A}$ increments the $\mathrm{CO}_{2}$ emissions, while Case $\mathrm{B}$ reduces the green house gases emission by $13.2 \%$.

Moreover, we underline that the results of this study could have a huge impact in practical applications. In fact, the residential sector can be considered a promising market for distributed energy systems. In the US, every year more than 1 Million of new residential units are built [93] and the trend is positive. Given that the CHP system in study can satisfy the energy demand of 20-30 families, a potential market of 40000 units per year can be estimated, for just the US scenario. This would result also in a drastic reduction of the technology cost [42, 48].

The analysis here performed could be further refined considering more advanced fuel processors for the CHP systems and different technologies for the low temperature thermally activated cooling machines. Moreover, the matching with the energy demand of several buildings types, such as clinics, hotels, supermarkets, and restaurants could be investigated. Finally, we note that the cluster of tools here presented could be used to properly size a distributed energy system, performing complete business case analysis.

\section{Acknowledgment}

This project has received funding from the Fuel Cells and Hydrogen Joint Undertaking under grant agreement $N^{\circ} 671396$. This Joint Undertaking receives support from the European Union's Horizon 2020 research and innovation programme and United Kingdom, Germany, Greece, Croatia, Italy, Switzerland, Norway. Swiss partners are funded by the State Secretariat for Education, Research and Innovation of the Swiss Confederation.

\section{References}

[1] L. F. Cabeza, D. Urge-Vorsatz, M. A. McNeil, C. Barreneche, S. Serrano, Investigating greenhouse challenge from growing trends of electricity consumption through home appliances in buildings, Renewable and Sustainable Energy Reviews 36 (2014) 188-193.

[2] D. Ürge-Vorsatz, L. F. Cabeza, S. Serrano, C. Barreneche, K. Petrichenko, Heating and cooling energy trends and drivers in buildings, Renewable and Sustainable Energy Reviews 41 (2015) 85-98.

[3] S. Serrano, D. Ürge-Vorsatz, C. Barreneche, A. Palacios, L. F. Cabeza, Heating and cooling energy trends and drivers in europe, Energy 119 (2017) 425-434.

[4] International Energy Agency, Combined heat and power Evaluating the benefits of greater global investment (2008).

[5] F. Cappa, A. L. Facci, S. Ubertini, Proton exchange membrane fuel cell for cooperating households: A convenient combined heat and power solution for residential applications, Energy 90 (2015) 1229-1238.

[6] E. Jannelli, M. Minutillo, A. Perna, Analyzing microcogeneration systems based on LT-PEMFC and HT-PEMFC by energy balances, Applied Energy 108 (2013) 82-91.

[7] S. Pellegrino, A. Lanzini, P. Leone, Techno-economic and policy requirements for the market-entry of the fuel cell micro-CHP system in the residential sector, Applied Energy 143 (2015) 370-382.

[8] A. Adam, E. S. Fraga, D. J. Brett, Options for residential building services design using fuel cell based micro-CHP and the potential for heat integration, Applied Energy 138 (2015) 685-694.

[9] F. Calise, R. D. Figaj, N. Massarotti, A. Mauro, L. Vanoli, Polygeneration system based on pemfc, cpvt and electrolyzer: Dynamic simulation and energetic and economic analysis, Applied energy 192 (2017) 530-542.

[10] E. Jannelli, M. Minutillo, R. Cozzolino, G. Falcucci, Thermodynamic performance assessment of a small size cchp (combined cooling heating and power) system with numerical models, Energy 65 (2014) 240-249.

[11] N. Sammes, R. Boersma, Small-scale fuel cells for residential applications, Journal of Power Sources 86 (12) (2000) $98-110$.

[12] H. Onovwiona, V. Ugursal, Residential cogeneration systems: review of the current technology, Renewable and Sustainable Energy Reviews 10 (5) (2006) $389-431$.

[13] F. Barbir, Pem fuel cells, in: Fuel Cell Technology, Springer, 2006, pp. 27-51.

[14] R. O'hayre, S.-W. Cha, F. B. Prinz, W. Colella, Fuel cell fundamentals, John Wiley \& Sons, 2016.

[15] F. Baratto, U. M. Diwekar, D. Manca, Impacts assessment and tradeoffs of fuel cell based auxiliary power units: part ii. environmental and health impacts, lca, and multi-objective optimization, Journal of power sources 139 (1) (2005) 214-222.

[16] S. Singhal, Advances in solid oxide fuel cell technology, Solid state ionics 135 (1) (2000) 305-313.

[17] T. Ackermann, G. Andersson, L. Söder, Distributed generation: a definition, Electric power systems research 57 (3) (2001) 195-204.

[18] J. Sadhukhan, Distributed and micro-generation from biogas and agricultural application of sewage sludge: Comparative environmental performance analysis using life cycle approaches, Applied Energy 122 (2014) 196-206.

[19] F. C. Today, The fuel cell industry review 2013, Tech. rep., Fuel Cell Today (2013).

URL http://www. fuelcelltoday.com/media/1889744/\। fct \_review $\backslash$ 2013.pdf.

[20] R. Cozzolino, L. Tribioli, G. Bella, Power management of a hybrid renewable system for artificial islands: A case study, Energy 106 (2016) 774-789.

[21] Y. Zhang, A. Lundblad, P. E. Campana, J. Yan, Comparative study of battery storage and hydrogen storage to increase photovoltaic selfsufficiency in a residential building of sweden, Energy Procedia 103 (2016) 268-273.

[22] International Energy Agency, Medium-Term Renewable Energy Market Report, OECD/IEA., http://www.iea.org/textbase/npsum/ mtrenew2013sum.pdf (2013).

[23] D. Hart, F. Lehner, R. Rose, J. Lewis, M. Klippenstein, The fuel cell industry review 2017, Tech. rep., E4tech (2017). URL http: / / www. fuelcellindustryreview. com/

[24] F. C. Handbook, Eg\&g technical services, Inc., Albuquerque, NM, DOE/NETL-2004/1206. 
[25] D. Carter, Fuel cell residential micro-CHP developments in Japan, Tech. rep., Fuel Cell Today (2012).

URL http: / / www. fuelcelltoday.com/media/1597029/\। 29-02-12\_ene-farm.pdf

[26] G. Chicco, P. Mancarella, Distributed multi-generation: A comprehensive view, Renewable and Sustainable Energy Reviews 13 (3) (2009) 535 551.

[27] International Energy Agency, Distributed Generation in Liberalised Electricity Markets (2002).

[28] K. Lau, M. Yousof, S. Arshad, M. Anwari, A. Yatim, Performance analysis of hybrid photovoltaic/diesel energy system under malaysian conditions, Energy 35 (8) (2010) 3245 - 3255.

[29] A. Franco, P. Salza, Strategies for optimal penetration of intermittent renewables in complex energy systems based on techno-operational objectives, Renewable Energy 36 (2) (2011) 743 - 753.

[30] M. Naqvi, E. Dahlquist, J. Yan, Complementing existing chp plants using biomass for production of hydrogen and burning the residual gas in a chp boiler, Biofuels (2016) 1-9.

[31] A. L. Facci, V. Cigolotti, E. Jannelli, S. Ubertini, Technical and economic assessment of a sofc-based energy system for combined cooling, heating and power, Applied Energy.

[32] J. Deng, R. Wang, G. Han, A review of thermally activated cooling technologies for combined cooling, heating and power systems, Progress in Energy and Combustion Science 37 (2) (2011) 172-203.

[33] P. Srikhirin, S. Aphornratana, S. Chungpaibulpatana, A review of absorption refrigeration technologies, Renewable and sustainable energy reviews 5 (4) (2001) 343-372.

[34] H. Demir, M. Mobedi, S. Ülkü, A review on adsorption heat pump: Problems and solutions, Renewable and Sustainable Energy Reviews 12 (9) (2008) 2381-2403.

[35] K. Daou, R. Wang, Z. Xia, Desiccant cooling air conditioning: a review, Renewable and Sustainable Energy Reviews 10 (2) (2006) 55-77.

[36] A. L. Facci, S. Ubertini, Analysis of a fuel cell combined heat and power plant under realistic smart management scenarios, Applied Energy 216 (2018) 60-72.

[37] Ballard, ClearGen specification sheet.

URL http://pdf.directindustry.com/pdf/ballard/\ cleargen-multi-mw-systems/22779-383697.html

[38] Ballard, Economics of Fuel Cell Solutions for Backup Power. URL http: / /ballard.com/files/PDF/Backup \_Power/ \ BUP \_EmrgncyEcon\_EGen\_091712-01.pdf

[39] Micro-CHP, PEM fuel cells

URL http://www.microchap.info/pem\_fuel】_cells. htm

[40] Doosan, PuroCell Model 400.

URL http://www.doosanfuelcell.com/attach】files/

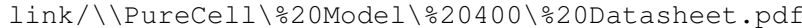

[41] Elcore $2400 \mathrm{Max}$ - das Komplettpaket.

URL http://www.elcore.com/elcore-energiesysteme/ \lelcore-2400-max/

[42] I. Staffell, R. Green, The cost of domestic fuel cell micro-chp systems, International Journal of hydrogen energy 38 (2) (2013) 1088-1102.

[43] Inhouse engineering, Fuel cell $\mu \mathrm{CHP}$ system inhouse5000+.

URL https://www.inhouse-engineering. com/en/fuel-cell \\-systems/products / fuel-cell-chp-system- \\inhouse5000plus/

[44] Tropical Green technologies, $5 \mathrm{~kW}$ Hydrogeno Fuel Cell Generator. URL http://www.tropical.gr/fuel-cell-power-। Igenerators/5kw-fC-power-generator.html\$ sharp\$5kw $\backslash 2$

[45] Fuel cell boiler Vitovalor 300-P

URL http://www.viessmann.co.uk/en/residential/ $\backslash$-buildings/combined-heat-and-power-generation/ $\backslash \backslash$ micro-chp-unit-based-on-a-fuel-cell/ vitovalor- $\backslash \backslash 300 \mathrm{p} \cdot \mathrm{html}$

[46] Fuel cells and hydrogen joint undertaking (FCH JU) multi-annual work plan 2014-2020.

URL http: / / www. fch. europa.eu/sites/default/files/ $\backslash \backslash \mathrm{FCH} 2 \backslash \div 20 \mathrm{JU} \backslash \div 20-\backslash \div 20 \mathrm{Multi} \backslash \div 20 \mathrm{Annual} \backslash \div 20 \mathrm{Work} \backslash$ $\div 20 \mathrm{P} \operatorname{lan} \backslash \div 20 \backslash \backslash-\backslash \div 20 \mathrm{MAWP} \backslash \div 20 \backslash \div 28 \mathrm{ID} \backslash \% 20623483 \backslash \div 29$. $\mathrm{pdf}$
[47] J. Spendelow, J. Marcinkoski, D. Papageorgopoulos, Micro CHP fuel cell system targets (2012).

URL https : / /www. hydrogen. energy.gov/pdfs/ \\11016 _micro\_chp\_target.pdf

[48] B. D. James, A. B. Spisak, W. G. Colella, Manufacturing cost analysis of stationary fuel cell systems, Tech. rep., Strategic Analysis (2012).

[49] M. R. Weimar, L. A. Chick, G. D. W, G. A. Whyatt, Cost study for manufacturing of solid oxide fuel cell power systems, Tech. Rep. PNNL-22732, U.S. Department of Energy (2012).

[50] AutoRe (2016).

URL https: / / www . autore-eu.com/

[51] European Commission, CORDIS the Community Research and Development Information Service.

URL https://cordis.europa.eu/project/rcn/197929_ en.html

[52] R. Cozzolino, Thermodynamic performance assessment of a novel microcchp system based on a low temperature pemfc power unit and a halfeffect li/br absorption chiller, Energies 11 (2).

URL http: / / www . mdpi.com/1996-1073/11/2/315

[53] A. L. Facci, G. Loreti, S. Ubertini, F. Barbir, T. Chalkidis, R.-P. Eßling, T. Peters, E. Skoufa, R. Bove, Numerical assessment of an automotive derivative CHPfuel cell system, in: Proceedings of the 8'th International Conference on Applied Energy, Elsevier, 2016.

[54] A. L. Facci, G. Loreti, P. Thijs, S. Ubertini, Numerical modeling of an automotive derivative pem fuel cell chp system with selective membranes.

[55] G. Loreti, A. L. Facci, T. Peters, S. Ubertini, Numerical modeling of an automotive derivative polymer electrolyte membrane fuel cell cogeneration system with selective membranes, International Journal of Hydrogen Energy.

[56] A. L. Facci, L. Andreassi, S. Ubertini, Optimization of chcp (combined heat power and cooling) systems operation strategy using dynamic programming, Energy 66 (2014) 387-400.

[57] A. L. Facci, L. Andreassi, S. Ubertini, E. Sciubba, Analysis of the influence of thermal energy storage on the optimal management of a trigeneration plant, Energy Procedia 45 (2014) 1295-1304.

[58] A. L. Facci, L. Andreassi, F. Martini, S. Ubertini, Comparing energy and cost optimization in distributed energy systems management, Journal of Energy Resources Technology 136 (3) (2014) 032001.

[59] A. L. Facci, S. Ubertini, Meta-heuristic optimization for a high-detail smart management of complex energy systems.

[60] T. A. Peters, R. Bredesen, H. J. Venvik, Pd-based membranes in hydrogen production: Long-term stability and contaminant effects, in: Membrane Engineering for the Treatment of Gases, 2017, pp. 177-211.

[61] A. Piga, X. E. Verykios, An advanced reactor configuration for the partial oxidation of methane to synthesis gas, Catalysis today 60 (1) (2000) 6371.

[62] European Patent 94600005.6/13.07.94. U.S.A. Patent No. 6, 605376 Aug. 12 .2003.

[63] I. Dybkjaer, Tubular reforming and autothermal reforming of natural gas - an overview of available processes, Fuel Processing Technology 42 (2) (1995) 85 - 107, trends in Natural Gas Utilisation.

URL http: //www.sciencedirect.com/science/article/ pii/037838209400099F

[64] A. Perna, S. Cicconardi, R. Cozzolino, Performance evaluation of a fuel processing system based on membrane reactors technology integrated with a pemfc stack, international journal of hydrogen energy 36 (16) (2011) 9906-9915.

[65] A. Heinzel, B. Vogel, P. Hübner, Reforming of natural gashydrogen generation for small scale stationary fuel cell systems, Journal of Power Sources 105 (2) (2002) 202-207.

[66] Fuel Cell Standards Committee and others, Information report on the development of a hydrogen quality guideline for fuel cell vehicles, sae, j2719, International Organization for Standardization, Hydrogen FuelProduct Specification-Part 2 14687-2.

[67] K. E. Herold, R. Radermacher, S. A. Klein, Absorption chillers and heat pumps, CRC press, 2016.

[68] B. H. Gebreslassie, M. Medrano, D. Boer, Exergy analysis of multi-effect water-libr absorption systems: from half to triple effect, Renewable Energy 35 (8) (2010) 1773-1782.

[69] ASHRAE, Product directory ashrae handbook, System 1974

[70] Aspen, Aspenplus (2016) 
URL

http://www.aspentech.com/products/

engineering $\backslash \backslash /$ aspen-plus /

[71] Z. Yang, X. Tang, M. Qu, O. Abdelaziz, K. R. Gluesenkamp, Development of updated absorption simulation software (absim), Tech. rep., Oak Ridge National Laboratory (ORNL); Building Technologies Research and Integration Center (BTRIC) (2014).

[72] G. Grossman, A. Zaltash, Absimmodular simulation of advanced absorption systems, International Journal of Refrigeration 24 (6) (2001) 531543.

[73] S. A. Klein, F. Alvarado, EES: Engineering equation solver for the Microsoft Windows operating system, F-Chart software, 1992.

[74] H. Yin, An absorption chiller in a micro bchp application: model based design and performance analysis, Ph.D. thesis, Citeseer (2006)

[75] M. H. Beitelmal, C. D. Patel, Model-based approach for optimizing a data center centralized cooling system, Hewlett-Packard (HP) Lab Technical Report.

[76] R. Maryami, A. Dehghan, An exergy based comparative study between libr/water absorption refrigeration systems from half effect to triple effect, Applied Thermal Engineering 124 (2017) 103-123.

[77] C. Somers, A. Mortazavi, Y. Hwang, R. Radermacher, P. Rodgers, S. AlHashimi, Modeling water/lithium bromide absorption chillers in aspen plus, Applied Energy 88 (11) (2011) 4197-4205.

[78] O. Redlich, J. N. Kwong, On the thermodynamics of solutions. v. an equation of state. fugacities of gaseous solutions., Chemical reviews 44 (1) (1949) 233-244.

[79] H. Renon, J. M. Prausnitz, Local compositions in thermodynamic excess functions for liquid mixtures, AIChE journal 14 (1) (1968) 135-144.

[80] ASHRAE, Ashrae handbook fundamentals (1989).

[81] F. Kreith, R. M. Manglik, M. S. Bohn, Principles of heat transfer, Cengage learning, 2012.

[82] E. Fabrizio, M. Filippi, J. Virgone, An hourly modelling framework for the assessment of energy sources exploitation and energy converters selection and sizing in buildings, Energy and Buildings 41 (10) (2009) 1037-1050.

[83] A. Hawkes, M. Leach, Cost-effective operating strategy for residential micro-combined heat and power, Energy 32 (5) (2007) 711-723.

[84] L. Andreassi, M. Ciminelli, M. Feola, S. Ubertini, Innovative method for energy management: Modelling and optimal operation of energy systems, Energy and Buildings 41 (4) (2009) 436-444.

[85] D. Chiappini, A. L. Facci, L. Tribioli, S. Ubertini, SOFC management in distributed energy systems, Journal of Fuel Cell Science and Technology $8(3)$.

[86] L. Tribioli, R. Cozzolino, L. Evangelisti, G. Bella, Energy management of an off-grid hybrid power plant with multiple energy storage systems, Energies 9 (8) (2016) 661.

[87] Office of Energy Efficiency and Renewable Energy, Commercial reference buildings, http://energy.gov/eere/buildings/commercial-referencebuildings (November 2016)

[88] M. J. Laustsen, Energy efficiency requirements in building codes, energy efficiency policies for new buildings (2008).

[89] Joint Research Center, Photovoltaic geographical information system (pvgis), http://re.jrc.ec.europa.eu/pvgis/ (March 2018).

[90] Eurostat, Eurostat, your key to european statistics (2016).

URL http: / / ec. europa.eu/eurostat/web/energy/data/ $\backslash \backslash$ database

[91] D. Sari, A. Bayram, Quantification of emissions from domestic heating in residential areas of izmir, turkey and assessment of the impact on local/regional air-quality, Science of the Total Environment 488 (2014) 429-436.

[92] A. Moro, L. Lonza, Electricity carbon intensity in european member states: Impacts on ghg emissions of electric vehicles, Transportation Research Part D: Transport and Environment.

[93] The U.S. Census Bureau and the U.S. Department of Housing and Urban Development, Monthly new residential construction, february 2018. URL https://www. census.gov/construction/nrc/pdf/ newresconst.pdf 